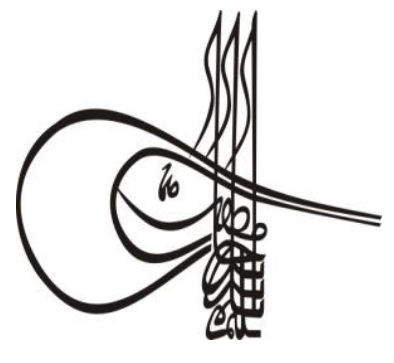

Received/Geliș: 04.09.2019

\section{Turkísh Gtudies}

Volume 14 Issue 7, 2019, p. 4031-4057

DOI: 10.29228/TurkishStudies.36883

ISSN: 1308-2140

Skopje/MACEDONIA-Ankara/TURKEY

Research Article / Araștırma Makalesi

Article Info/Makale Bilgisi

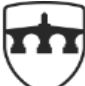

INTERNATIONAL

BALKAN

UNIVERSITY

EXCELLENCE FOR THE FUTURE IBU.EDU.MK

$\checkmark$ Accepted/Kabul: 20.12.2019

Go Report Dates/Rapor Tarihleri: Referee 1 (20.11.2019)-Referee 2 (02.12.2019)

This article was checked by iThenticate.

\title{
21. YÜZYIL ÖĞRENCİLERİ İÇİN YENİ BİR YAKLAŞIM: BİLIŞSEL KOÇLUK
}

\author{
Seçil TÜMEN AKYILDIZ*
}

\begin{abstract}
ÖZ
Globalleşmenin getirilerine ayak uydurabilmek için eğitim alanında da devrim niteliğinde değişimler olmaktadır. Rogers'in (1951) hümanisttik psikoloji görüşü çerçevesinde öğreneni merkeze almanın gerekliliği eğitim uzmanlarınca da desteklenmektedir. Eğitim alanındaki bu değişim sürecin odağında bulunan öğrencilerin gelișimlerini ve hayat boyu öğrenme durumlarını destekledikçe kalıcı çözümlere ulaşabileceği açıktır. Zira içinde bulunduğumuz çağın gereği olarak yapılması gereken, öğrencileri özerk birer birey olarak eğitim sisteminin odak noktası haline getirmektir. Bu durumda da öğrencinin başarısının yanı sıra onu bilişsel ve kişisel olarak da geliştirmek ve desteklemek için yeni uygulamalara başvurmak kaçınılmazdır. Bu noktadan hareketle eğitim alanına kazandırılabilecek yeni yaklaşımlardan birisi de öğrencilere bilişsel koçluk uygulamalarıyla destek olmaktır. Bilişsel koçluğun temel misyonu; bilișsel kapasitesi ile hem bağımsız hem de bir topluluğun üyesi olarak yüksek performans sergileyebilen ve kendi kararlarını kendisi alarak uygulamaya geçirecek kapasiteye sahip, özerk bireyler yetiştirmektir. Eğitim sistemindeki yenileşme hareketleri kapsamında bilişsel koçluktan faydalanmak öğrencilerin hem kendi hem de başkalarındaki hüneri ortaya çıkarma noktasındaki gelişimleri için önem arz etmektedir. Bu alanda yapılmış olan çalışmalar incelendiğinde bilişsel koçluğun çoğunlukla öğretmenlere uygulandığı tespit edilmiş ve incelenen çalışmaların öğretmenlerdeki gelişimin eğitim ortamını ve öğrenciyi geliştirmesini saptamaya çalıștığı görülmüştür. Bunun yanı sıra öğrenciye uygulanan çalıșmaların oldukça sınırlı olduğu ortaya çıkmış olup ve bu kavramın detaylıca açıklanmasının alana katkı sağlayacağı ve öğrenci bağlamında kullanım sıklığının artacağ düşünülmektedir.
\end{abstract}

Anahtar Kelimeler: Bilişsel Koçluk, Koçluk, Hümanistik Yaklaşım, Öğrenen Merkezli Sistem 


\title{
A NEW APPROACH FOR THE STUDENTS OF 21ST CENTURY: COGNITIVE COACHING
}

\begin{abstract}
There are revolutionary changes in the field of education to keep up with the benefits of globalization. The necessity of taking the learner to the center within the framework of Roger's (1951) humanistic psychology is also supported by educationalists. It is clear that permanent solutions may be reached only if necessary support is given to the students for their cognitive-personal growth and lifelong learning process. Students should be on the focus of the educational system as autonomous individuals. Thus it is inevitable to apply new technics in educational settings not only to increase students' achievement but also support them cognitively and personally. Therefore, cognitive coaching is foreground as one of the new support technics for students growth in educational settings. The initial mission of cognitive coaching is to enhance one's ability to display high level of performance as autonomous individuals in terms of self-directedness and holonomy. Utilizing cognitive coaching in terms of innovation in educational settings becomes more of an issue on enhancing one's own and another's resourcefulness. Examining the research on the current field, it is observed that there is a number of research in which cognitive coaching was applied to teachers and the results were examined on behalf of educational system and students. However it is also investigated that there are few studies which observed the direct effects of cognitive coaching on students applying it to them. Hence by the help of this literature synthesis study it is thought that cognitive coaching practices on students will mount up and it will contribute to the field accordingly.
\end{abstract}

\section{STRUCTURED ABSTRACT}

Educators should take the learners to the center to comply with dramatic educational progress. In other words instead of sticking to the traditional educational practices educators should adopt to the improvement of individuals in terms of constructivism and humanistic psychology. As for Rogers (1983) in education, there has been a shift from teaching to learning to make the learnes independent and responbsible for their learnings and also help them to learn about how to learn instead of instructing them directly. Rogers (1983) stated that if the proper conditions were created for the learners there would be no reasons for them not to learn. Thus, instead of conveying the knowledge to the students, educators should help them to improve themselves in a holistic manner in terms of their skills and self-determination.

Cognitive coaching is one of the ways to make the aforementioned change possible for students. By the help of cognitive coaching schools can become better places to learn; a number of students can be empowered as self-directed learners and teachers can utilize more influential ways to reach their students (Costa and Garmston, 2002). In other words students may be supported to be autonomous learners, to solve complex problems, to think complicated and to be life-long 
learners if cognitive coaching is utilized in education. Hence cognitive coaching should be examined in terms of its exact meaning, benefits and process.

Cognitive Coaching unlike other forms of coaching, mentoring or supervising which focus on overt behaviours or events, is a unique interactive strategy in that it mediates one's internal mental sources and intellectual functions. The basic mission of cognitive coaching is to bring self directed people out. They are expected to show high performance with their cognitive capacity both being an independent agent and as a part of a greater system that means being holonomous. Cognitive coaching creates more successful school programs as it is regarded 'a modern Renaissance' in education (Costa and Garmston, 2002).

There are three mental maps which guide the cognitive coach in the process. They are the planning conversation which occusr before the task or an event, the reflecting conversation that occurs after the task or event and the problem solving conversation. The cognitive coaching process is a cyclic one which is a combination of the first two maps. Only if the people feel helpless the problem solving conversation map is used. Therefore the steps of the cognitive coaching cycle can be defined 'planning-observation-reflecting' (Costa and Garmston, 2002).

Aformentioned before the ultimate goal of cognitive coaching is to help the persons to become self-directed ones which means to selfmanage, self-monitor and self-modify themselves. In line with this goal the cognitive coach -the mediator- uses some well-crafted verbal such as paraphrasing, acknowledging and clarifying and non-verbal tools like paralanguage, to facilitate the others' self-growth (Costa and Garmston, 2002).

As seen, cognitive coaching is a very useful and flourishing method in educational settings. The studies on this field should be examined in detail to understand how to utilize it in different educational purposes. Edwards (2004) alalyzed the research on cognitive coaching so far and stated nine outcomes of cognitive coaching as below: teachers,

-Students' getting higher grades,-Increase in effectiveness of

-Increase in reflective and complex thinking of teachers

-Increase in teachers' satisfaction in terms of their career,

-Providing a more professional school environment,

-Providing a more collaborative setting for teachers,

-Increase in professional support which is provided for teachers,

-Teachers' being affected positively in terms of their personal growth, education

- Utilizing this method for different purposes apart from

To conclude, it is clear that the new paradigm of education is helping individulas to direct their own learning and to construct their 
own meanings by the help of their experiences. Thus new and promising methods enhance education by helping learners to learn about their learning. Educators should seek new ways that provide both teachers and students share meanings and give support to each other. At this point cognitive coaching is a very promising alternative to utilize.

Cognitive coaching and its impacts have been studied so far. When the research has examined, it is revealed that most of them were carried out on teachers. However more research is still needed in order to learn about why cognitive coaching should be utilized for students. As students are at the center of education they charge of their own learning, any kind of support is welcomed by them. In this era, education should be liberating. So, helping people learn to educate themselves is more important than to provide knowledge. Therefore cognitive coaching as a new approach should be used for students to make them control over their own learning.

Keywords: Cognitive Coaching, Coaching, Humanistic Approach, Learner-Centered System

\section{Giriş}

Globalleşmenin getirileriyle dünyamız artık olaylara, düşüncelere ve kişilere karşı esnekliği olmayan, başına gelebileceklere karşı hazırlıksız, başını kuma saklamış, çekingen ve kendini toplumdan soyutlamış bir şekilde yaşayan insanlar için uygun bir yer olmaktan çıkmıştır. Yeni düzene ayak uydurabilmek için; her türlü problemli durumdan etkili çözüm yollarıyla çıkabilen, yüksek düzeyde öz-yeterliğe sahip, nasıl daha iyi öğrenebileceğini bilen, yaratıcı, yeteneklerini hem yeni hem de bilindik durumlarda nasıl kullanacağını bilen, değerleri olan ve başkalarıyla uyumlu çalışabilen bireyler olmak gerekmektedir (Hase ve Kenyon, 2003). Bunun yanında, bilgiye ulaşabilen ve ulaştığı bilgiyi pratiğe dönüştürebilen, bireylere de gereksinim duyulmaktadır.

Globalleşmeye ayak uydurmanın kaçınılmaz olduğu çağımız, yukarıda sözü edilen nitelikte ürünler verebilmek için eğitim alanında da reform niteliğinde değişimlere sahne olmaktadır. Büyük resmi anlamlandırabilmek adına Blaschke ve Hase'nin (2014) belirttĭgi gibi eğitim alanında devrim niteliğinde olan ve uzun zamandan beri ayak seslerini duyduğumuz değişimin ne ifade ettiğini bilmek gereklidir. 20. Yüzyılın ikinci yarısından itibaren hissedilmeye başlanan değişimin temelleri halihazırda yaşadığımız eğitim ortamlarında bireyin kazandığ 1 değeri ön plana çıkaran Vygotsky'nin yapılandırmacı yaklaşımı ve de Rogers'ın hümanisttik psikoloji yaklaşımıdır (Blaschke ve Hase, 2014).

$\mathrm{Bu}$ alanda çığır açıcı görüşlere sahip olan ve geleneksel öğrenme psikoloğu kimliğinden sıyrılıp hümanisttik psikoloji ile adını duyuran Carl Rogers (1951), insanı; fiziksel, bilişsel ve daha önemlisi duygusal bir bütün olarak ele almış ve kişilerin öz kavramlarını geliştirmeye odaklanan prensipleriyle var oluş nedenlerini keşfetmelerini sağlamıştır. Bu bağlamda da kendi işlevlerinin tamamıyla farkında olan ve kendisini gerçekleştirmiş kişilerin tam potansiyellerine kavuşacaklarını ve daha iyi öğreneceklerini iddia etmiştir. Önem arz eden olayın, öğretme değil de öğrenme olması, bireye verilen önem ve değerin sonucudur. Rogers'a (1983) göre eğitimin amacı değişim ve ögrenmeden faydalanmaktır. Bu durumda, bireylerin özgür oldukları öğrenme ortamlarında onlara hazır bilgiyi sunmak yerine nasıl öğreneceklerini öğretmenin daha faydalı olduğu görüşü hümanisttik psikoloji yaklaşımının da temelinde yatmaktadır. Rogers (1983) bireylerin bilişsel ve duyuşsal anlamda hazır olduklarında ve de öğrenme için uygun ortam yaratıldığında ögrenmemeleri için hiçbir sebep olmadığını savunmaktadır. 
Rogers'ın (1951) da katkılarıyla eğitimde hümanisttik psikoloji yaklaşımı 20. yüzyılın sonlarına damgasını vurmuş ve 21 . yüzyılın da ayak sesleri niteliği taşımıştır. Bu çerçevede eğitimde nasıl düşünmesi ve öğrenmesi gerektiğini anlamış, yetenekli bireyler yetiştirmek için öğrenci merkezli yenilikçi yaklaşımların benimsenmesi gerekmektedir (Hase ve Kenyon, 2003). Bu yaklaşımlar yardımıyla da sadece bilgi ve becerinin edinildiği bir öğrenme deneyiminden ziyade öğrenenin hür iradesi ve yetenekleriyle bütüncül bir gelişim göstermesi hedeflenmektedir (Stephenson and Laycock, 2005).

$\mathrm{Bu}$ durumda öğretmenin sınıfta otoriter bilgeden kolaylaştırıcı rehbere dönüşümü (King, 1993, Levy-Feldman,2018) üst düzey düşünme becerisinin eğitimin her kademesine entegre edilmesi gerekliliği (Shaw, 2014), öğrenciye öğrenmeyi öğretmeyi hedef almanın kaçınılmazlığı (Novak ve Gowin,1984), sınıf içerisinde dolmayı bekleyen boş kaptan (Freire, 1970), ziyade bireysel farklılıklarıyla değerli olduğunun hissettirilmesi (Rogers, 1983) ve de öğrenciye yaşam boyu sürecek olan öğrenme yolculuğunda sadece profesyonel gelişiminde değil aynı zamanda kişisel gelişimi noktasında da yol göstermek (Levy-Feldman, 2018) eğitimin değişim kapsamına giren anahtar noktalardır. Bu durumda değişime ayak uydurmak ve öğrenmeyi kolaylaştırmak için her şeyden önce eğitimde odağın öğretmenden öğrenciye kaydığını (Rogers, 1983) ve 'öğrencinin sinıftaki gücünü' (Freire, 1970) yani özetle insanların öğrenme yollarında bir devrimin meydana geldiğini kabul etmek gerekir (Blaschke ve Hase, 2014).

Değişimin oldukça belirgin bir şekilde hissedildiği ve eğitim ortamlarında öğrencinin öğrenen özelliğiyle en ön planda tutulduğu çağımızda öğrencilere özerk öğrenen olmaları yolunda destek vermek, onlara karmaşık düşünebilecekleri yollar açmak, yaşam boyu sürecek olan öğrenme yolculuklarında nasıl daha iyi öğrenebileceklerini öğretme ve problem çözme becerisi kazandırmak bilişsel koçluk yardımıyla olacaktır. Bu desteğin eğitim ortamında öğretmen tarafından verilmesi elbette ki çok değerlidir. Ancak bazı kısıtlayıcı durumlarda (müfredat kaygısı-ders süreleri- sınav odaklı sistem) bu desteğin dişarıdan öğrenciye sağlanması da alternatif bir çözüm yolu olarak düşünülebilir. $\mathrm{Bu}$ durum göz önüne alındığında koçluğun tanımı kapsamında öğrencinin kendi eğitim alanı içinde olmayan birinden yukarıda bahsi geçen konularda destek alması onu yaşam boyu gelişimi noktasında destekleyecektir. Bilişsel Koçluk alan yazını incelendiğinde bu koçluk türünün büyük çoğunlukta öğretmenlere uygulandığı görülmektedir (Knaebel 2008; Reed 2006; Eger, 2006; Dougherty, 2000; Edwards vd., 1998; Edwards ve Green 1997; Ushijima, 1996; Awakuni, 1995, Edwards \& Newton, 1994). Ancak bilişsel koçluk kavramını ve uygulamalarını geliştiren fikir babaları Cost ve Garmston (2002) bu tip koçluğun öğrencilere de uygulanabileceğini ancak bu şekilde yapılan çalışmaların yetersiz olduğunu vurgulamışlardır. Yazarlara göre öğrencilere uygulanacak olan bilişsel koçluk onların bilişsel anlamda gelişimlerini sağlayacağı gibi bu koçluk sürecini öğrenmeleri birbirlerine de koçluk yaparak destek olmalarını sağlayacaktır.

Buradan hareketle mevcut çalışmada, bilişsel koçluk konusunun eğitim alanında daha yaygın kullanılması ve özelliklerinin daha iyi anlaşılması için sırasıyla, koçluk daha özelinde ise bilişsel koçluk kavramı; bilişsel koçluğun merkezinde olan zihin durumları; bilişsel koçluk sırasında uygulanan görüşmeler; bu görüşmeler esnasinda kullanılan araçlar ve de bu alanda yapılmış çalışmalar irdelenmiştir.

\section{Koçluk ve Bilişsel Koçluk}

Bilişsel koçluğu hizmet markası (SM) olarak eğitim dünyasına kazandıran Costa ve Garmston (2002), eğitim alanında oluşan bu yenileşme hareketlerini 'Modern Rönesans' benzetmesiyle resmetmiştir. Yazarlar, Rönesans hareketini zihin ve ruhu, duygular ve zekayı bir araya getirerek bütün içinde yeniden doğuş şeklinde açılamışlardır. Bu yeni bakış açısı içinde insan zihninin sınırlarının olmadığı, insanların bilgiyi yaşantıları yoluyla yapılandırdıkları, her yaştaki bireyin entelektüel gelişiminin devam ettiği, okul toplumunun tüm üyelerinin aktif ögrenenler olması gerektiği, özerk bireylerin aynı zamanda grupların da üyesi olarak işbirliği içinde 
çalışmalarının gerekliliği ve de bireylerin yenilenmek için sürekli olarak yansıtma yapmalarının kaçınılmazlığ bilişsel koçluğun temel prensipleriyle hemen hemen aynıdır. Eğitimde Rönesans okulu olarak da adlandırdıkları bu koçluk türünün temel misyonunu yazarlara göre; bilişsel kapasitesi ile hem bağımsız hem de bir topluluğun üyesi olarak yüksek performans sergileyebilen ve kendi kararlarını kendisi alarak uygulamaya geçirecek kapasiteye sahip, özerk bireyler yetiştirmektir.

Bilişsel koçluk kavramını detaylıca incelemeden önce genel olarak son yıllarda oldukça popüler olan 'koç' kavramını açıklamakta fayda vardır. Hase ve Kenyon (2003) öğrenmeye erişmeyi kolaylaştıran ve de deneyimler ve sosyalleşme yoluyla edinilip açık seçik ortaya konulmayan örtük bilgiye ulaştıran yollardan birinin koçluk olduğunu iddia etmektedir. Rutgers'e (2012, s.58) göre bu anlam yıllar içinde gelişmiş ve değişmiştir. Bu gün ise özel sektörde, okul ve spor sektöründe kullanılmaktadır. Eğitim sektöründeki koçluğun amacı liderlerin ve öğretmenlerin eğitim sürecinde karşılaştıkları zorluklarla mücadele etmelerini sağlamaktır. Reiss (2006, s.201) koçluğu kişilerin güçlü ve zayıf yönlerini ortaya çıkarmak için uygun bir strateji olarak tanımlar. Spence ve Oedas (2011, s.37) ise koçluğu bilgi, duygusal zeka ve öz düzenlemenin gelişimi yoluyla kişinin işlevselliğinin artması şeklinde açıklar. Whitemore'ın tanımı ise koçluğun eğitim alanındaki tanımlarından biri olabilir çünkü Whitemore (1995, s.8) koçluğu kişinin kendi performansını en üst düzeye çıkarması için kilidini açmak olarak görür. Koç öğretmez, kişiye öğrenmesi konusunda yardımcı olur. Koçlukla ilgili yapılan metaforlardan amacı doğrultusunda en ilgi ekici olanlardan biri Evered ve Selman (1989) tarafından alan yazına kazandırılmıştır. İngilizce 'coach' sözcügünün yaygın kullanılan ilk anlamı 'otobüs' tür. Evered ve Selman (1989) koçun tıpk1 bir ulaşım vasıtası olan otobüs gibi kişileri oldukları yerden olmak istedikleri yere taşıyan aracılar olduklarını ifade etmişlerdir. Joyce ve Showers (1995) yaptıkları birçok araştırmayla eğitim ortamlarındaki yenilikçi uygulamaların koçluk bileşeni olmadan tam istenilen etkiye ulaşmayacağını çarpıcı sonuçlarla sergilemişlerdir. Araştırmacılara göre teori ve demonstrasyonu kombine eden sınıf uygulamaları bile tek başına \%5 etkiye sahipken, bu oran sınıf uygulamaları, peşin hükümsüz dönütler ve de öğretim programının yeniliklere adapte edilmesiyle yükselebilmektedir. Ancak eğitim tasarlanırken eğitim dahilindeki kişilerin gelişimleri koçluk dahil edilerek olursa sınıf uygulamalarındaki etki oranının \% 90'a kadar çıkabileceği araştırmalarının en göze çarpan sonuçları arasında yer almıştır. Bu tanımlara göre 'koç' kişilerin yaşamlarına her açıdan pozitif değişiklikler getirmektedir. Rowley (1999,s. 21-22)' e göre ise iyi bir koç:

-Empati kurar ve yargılamadan, karşısındaki kişiyi kişisel değerleri ve inançları bir tarafa bırakarak kabul eder.

- Karşısındaki kişiyi gelişmekte olan bir birey olarak görür ve onu öğretici bir şekilde destekler. isteklidir.

- Karşısındaki kişinin beceri seviyesi ne olursa olsun onu desteklemeye

- Amaci öğrenmeyi desteklemek ve artırmaktır.

- Sürekli öğrenir. Mesleki olarak gelişiminin peşindedir.

- Yeni öğrendiklerini karşısındakiyle paylaşır.

Baker'a (2008, s.10-11) göre ise iyi bir koç iyi bir gelecek için umut ve iyimserlik yoluyla iletişim kuran kişidir. Koçluk yaptığı kişinin de kariyerinde onuru ve doyumu bu yolla bulmasını sağlamaya çalışır. Kendi mücadelesini ve hayal kırıklıklarını paylaşarak bu sıkıntılı süreçleri nasıl atlattığını göstermeye çalışır. Bunları öyle bir diyalog ortamı içerisinde yapar ki karşılıklı güveni ve saygıyı da inşa eder. Araştırma kapsamında eğitim alanındaki koçluk türlerinden bilişsel koçluğu irdelemek gerekir. 
Bilişsel koçluk, bireyleri içinde bulundukları ortamın kültürüne uyum sağlayabilmeleri için; yansıtma yapma, üst düzey düşünme becerilerine sahip olma ve dönüşümsel öğrenme alanlarında desteklemek için yapılır (Ellison ve Hayes, 2009). Costa ve Garmston (2002) da, daha çok öğrencinin etkin olduğu, öğrenme-öğretme ortamında doyuma ulaşlan, öğrencilerin özerk öğrenene dönüşerek güçlendiği ve de öğrenmeyi teşvik etmek için her seferinde daha etkili yollar denenen eğitim ortamlarının olmazsa olmazının -bilişsel koçlar- olduğunu ileri sürmektedirler Yust'a (1998, s.21) göre kişinin olayları yeni gözlerle görebilmesi için bilişsel koç ayna görevi yapar. Var olan güçlü yönleri desteklerken, keşfedilmemiş yönlerini bulmasında da kişiye yardımc1 olur. Diaz'a (2013, s.30) göre Bilişsel koç koçluk yaptığı kişileri düşünmeye teşvik eder. Yansıtma ve üstbilișsel süreçleri kullanarak karşısındaki kișinin kavrayıșını ve farkındalığını geliștirmeyi hedefler. Bilinen bilişsel koçluk Gomez (2005, s.5)'e göre kendi öğretim süreçlerini değerlendiren öğretmenler için kullanılan bir kavramdır. Diaz da 2013 yılında yürüttüğü çalışmasında yansitıcı uygulamalarını bilişsel koçluk yöntemiyle harmanlamış ve bu şekilde öğretmenlerin etkinliklerini artırarak öğrenci başarılarını da olumlu yönde etkilediğini belirtmiştir. Costa ve Garmston (2002, s.5) bilişsel koçluğun, peşin hükümsüz, gelişimsel ve yansıtıcı bir model olduğunu ileri sürerler. Bilişsel koçluğu Costa ve Garmston $(2002$, s.4) planlama, yansıtma ve problem çözme hakkında iletişim kurmanın basit bir modeli olarak tanımlarken, Townsend (1995, s.169-170) öğretmene karar verme ya da yansıtma sürecini öğretmek ve bu konuda öğretmenin gelişmesini sağlamak için kullanılan kapsamlı stratejiler bütünü olarak tanımlar. Cochran ve DeChesere $(1995$, s.24) ise değerli bir meslektaşa uzmanlık gelişimi yolunda yardım etmek için kullanılan bilinçli ve sistematik bir yaklaşım olarak tanımını yaparken bilişsel koçluğun öğretmenin yenilenmesini destekleyen kişisel ve güçlü bir metot olduğunu savunur. Yazarlara göre bilişsel koçluk uygulamaları eğitim sistemindeki buzların çözülmesine de yardımcı olacak ve sistemi geleneksellikten kurtaracaktır.

Bilişsel koçluğun tarihsel alt yapısı incelendiğinde, kavramın 1984 yılında bir takım yazarlar ve kurumsal görevliler tarafından öğretmen denetimi için geliştirildiği görülmektedir. Yıllar içinde bilişsel koçluk kavramının kullanımı ve yapısı değişmiş ve gelişmiştir. 1960'ların sonlarında Cogan ve arkadaşları öğretmenlikte başarısızlıkla sonuçlanan denetim işini denetmenlerin dikte edip, ögretmenlerin dinleyip uyguladıkları şekilden çıkarmak için klinik (objektif) denetim modelini geliştirmişlerdir. Bu modelde karşılıklı iletişim ve etkileşim yoktur; sadece denetmen konuşur, ögretmen dinler. Bilişsel koçluğun kendine özgü niteliklerini değerlendirmek için bu modelin anlaşılması önemlidir (Costa ve Garmston, 2002, s.8).

Cogan (1973, s.9) klinik denetimi öğretmenin sınıf içi performansını geliştirmek için dizayn edilen uygulama olarak tanımlar. Klinik denetim temel verilerini sınıf içi olaylardan alır. Elde edilen verilerin analizi öğretmenin sınıftaki tutum ve davranışlarının gelişimi yoluyla öğrenci gelişimini sağlar. Flanders'a (1976, s.47-48) göre klinik denetim, öğretimde yapılacak bazı değişiklikleri teşvik eder. Bu değişiklikler de öğretim sürecine ilişkin öğretmene faydalı bilgiler kazandırır. Cooper (1984, s.2) denetmen ve öğretmen arasındaki karşılıklı ilişkinin denetmen ve astı şeklinde değil de; birlikte çalışan iki meslektaş şeklinde olması gerektiğini savunmaktadır. Goldhammer ve diğerlerine göre (1980, s.19) denetmenler öğretmenlerle, sınıfta oluşan problemler ya da öğretmenlerin kendi belirledikleri ve daha fazla bilgi sahibi olmak istediği konular hakkında konuşmaya istekli olmalı ve öğretimsel gelişim için yüz yüze etkileşim içinde olmalıdır

Cogan'ın klinik denetim modeli öğretim öncesi öğretmenle planlama ve görüşme, dersi gözlemleme, dersten sonra tamamlayıcı bir görüşme yapma eylemleri çerçevesinde düzenlenen sekiz evreli döngüsel bir süreç olarak tasarlanmıştır. Cogan öğretim eylemini anlaş1labilir ve kontrol edilebilir davranışların derlenmesi olarak görmektedir. Bu davranışlar sadece etkileşim ile gözlemlenebilir. Öğretimde meydana gelecek gelişme ise bu davranışlarda meydana gelen gelişme ile paraleldir (Costa ve Garmston, 2002, s.8-9). 
Bilişsel koçluk kavramı, klinik denetim kavramından iki noktada ayrılır. Bunlardan ilki öğretim eyleminin algılanış biçimi; ikincisi ise öğretmenin bilişsel, nörolojik ve psikolinguistik ile ilgili özel bilgisinin uygulanışıdır. Geleneksel klinik denetim modeli açıkça öğretmen davranışını irdelerken, bilişsel koçluk bu davranışların içsel düşünce sürecinin ve entelektüel fonksiyonların ürün ve eseri olduğuna inanır. Öğretimin ön gördüğü davranış değişikliği görünür olmayan, içsel ve bilişsel davranışların yeniden düzenlenmesi ve değişimidir (Costa ve Garmston, 2002, s.9).

Geleneksel bir model olan klinik denetlemeden ayrılan bilişsel koçu, literatürde mentor denilen danışmandan da ayırmak gerekir. Barkley (2005, s.24-25)'e göre mentor da koç da kişiyi başarması adına güçlendirmektedir. Ancak mentorlukta eksik olan bir şeyler var ve tamir edilmeleri gerekirken; koçluk kişiyi güçlü yönlerini keşfedip gerçekleştirmesi için cesaretlendirir. Mentorluk da koçluk da öğretmenlerin mesleki gelişimleri için önemlidir. Her birinin kendine göre önemli yanları ve amaçları vardır ancak koçluk daha güçlüdür ve destek ortaklığı ve gelişim kaynaklıdır.

Klinik denetim modelinden ayrılan bilişsel koçluğun dayandığı felsefi, psikolojik, fizyolojik, ve tarihi kavramların bağlantıları ve ilişkileri aşağıdaki ağaç figürüyle açık bir şekilde gözler önüne serilmiştir. 


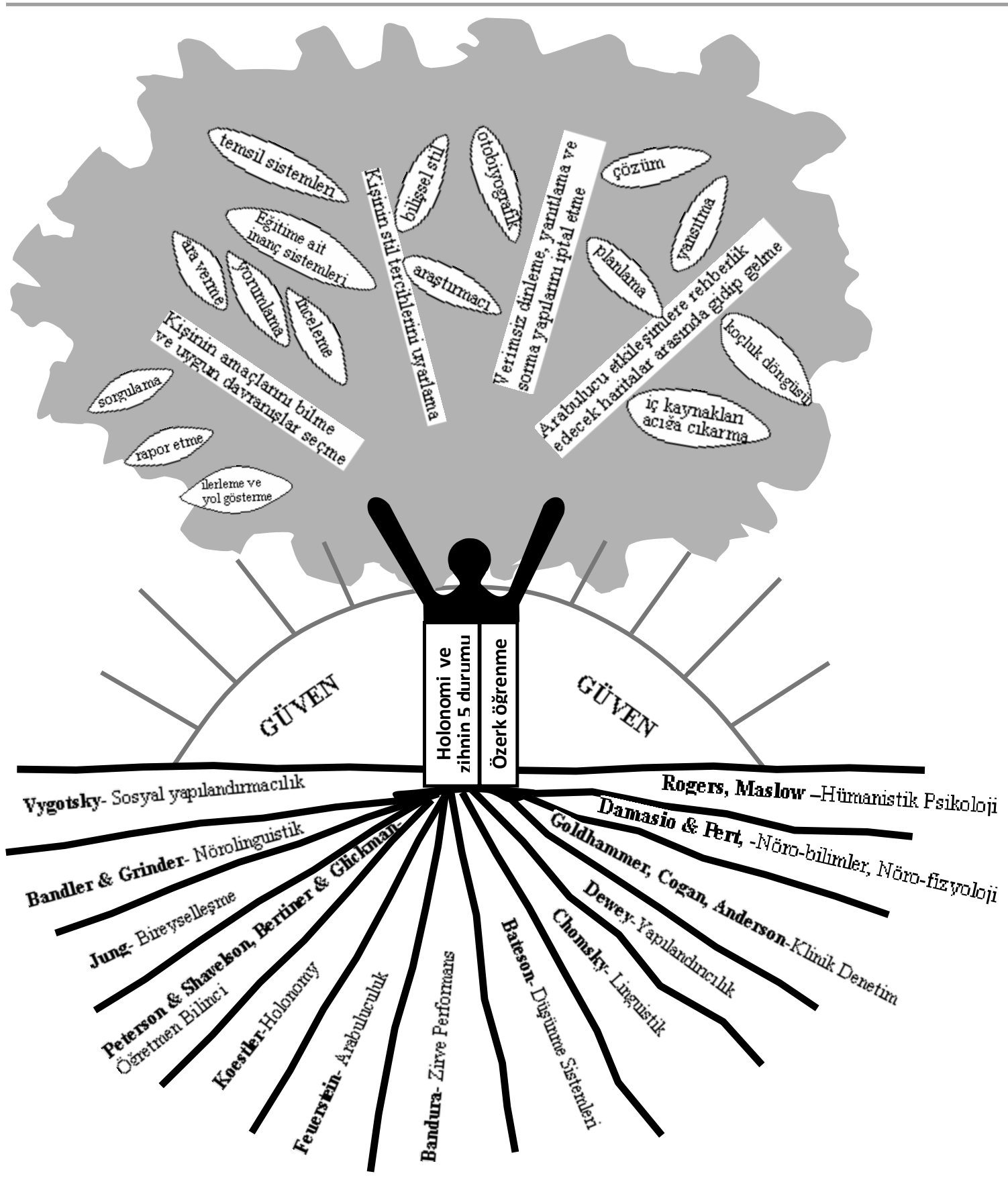

C BilisCenter for Cognitive Coaching

Şekil 1: Bilişsel koçluğun kökleri (Costa ve Garmston, 2002, s.10).

Bilişsel koçluğun temel dayanağı, her bireyin içinde değişim ve gelişimle ilgili bir kaynağın bulunduğuna dair inanç ve bu kaynağın dışarıdan destek sayesinde ortaya çıkacağına dair geliştirilen tutumdur (Gündüz ve Balyer, 2011, s.63). Kısacası her insanın içinde gelişim ve 
değişim heveslisi bir dev uyumakta ve bu devi uyandırmada da dışarıdan bir destek gerekmektedir. Eğitim ögretim ortamında da öğrenci ya da öğretmenlerin içlerindeki devi uyandırmada bilişsel koçluk yöntemi uygulanabilir bir yöntemdir.

“Öğretim ortamında koçluğu neden uygulamalıyız?" sorusuna Costa ve Garmston (2002, s.21-26) sekiz cevap vermiştir. Bunlar:

1. Öğretmenler desteğe ihtiyaç duyarlar.

2. $\quad$ Bilişsel Koçluk ögretmenlerin entelektüel kapasitelerini artırarak ögrencilerin entelektüel başarılarını artırır.

3. $\quad$ Eğitim alanında yapılan yenilikler koçluk bileşeni olmaksızın tam etki sağlayamaz.

4. Dönüt kendini yenilemenin enerji kaynağıdır.

5. Yeni öğretmenlerin bilişsel koçluğu benimseyen danışmanlara ihtiyacl vardir.

6. $\quad$ Etkili bir takım çalışması için koçluk gereklidir.

7. Koçluk okul kültürü ve verimli organizasyonlara kaynak olabilecek nitelikte kişiler arasında pozitif iliş̧kiler geliş̧tirir.

8. Koçluk, daha başarılı okul yenileme programları yapar ve destekler.

Bilişsel koçlar insanları grup içinde kendilerini yönlendirebilen, özerk bireyler olmaları noktasında desteklerler. Eger'e (2006, s.49) göre özerk öğrenenler yani kendi kendilerini öğrenme konusunda yönlendirebilen bireyler etraflarında ne olup bittiği konusunda oldukça duyarlıdırlar ve başarı için çeşitli yollar geliştirirler. Costa ve Garmston (2002, s.20-22) yetenekli bir bilişsel koçun aşağıdaki özelliklere sahip olması gerektiğini belirtir:

- Kişinin kendisinde, ilişkilerde, süreçte ve ortamda güven oluşturur ve onu devam ettirir.

•Öz yönetimli öğrenme oluşturma niyetiyle etkileşime girer.

-Zihin durumlarını aklında canlandırır, değerlendirir ve aracılık yapar.

-Zihin durumlarını geliştirecek stratejiler geliştirir ve onları uygular.

Bilişsel koçluğun temel misyonu; yüksek performans sergilemek için yeterli bilişsel kapasiteye sahip özerk bireyler oluşturmaktır. Bu bireyler bağımsız olmalarının yanı sıra bir topluluğun da üyesi olmalıdırlar. Bağımsız ve karşılıklı bağımlı ortamlarda özerk olmak holonomi (bütün içinde karşılıklı etkileşen bölümler) ile ilgilidir (Costa ve Garmston, 2002, s.16-18). Bilişsel koçluk çerçevesinde önemli kavramlardan biri olan holonomi birçok büyük sistemin parçasıyken tek olmak ve bağımsız bir özneyken aynı zamanda bir grubun üyesi olmak olarak tanımlanır. Hem bağımsız bir birey hem de bir grubun üyesi olan bir kişi:

- Benlik davası ve entegrasyon arasında seçenekler bulur.

- Ön bilgilerden, duyusal verilerden ve sezgilerden yararlanarak eylemlere rehberlik eder ve onları geliştirir.

- Belirsizliğin ve yeni anlamlar oluş̧urma imkânlarının peşinden gider. 
-Yalnızlık-birliktelik, eylem-yansıtma ve kişisel-profesyonel amaçlar arasında denge arayışındadır.

-Zengin içerikli yanıtlar üretmek için kendisininkinden farklı bakış açıları arar (Costa ve Garmston, 2002, s.20).

$\mathrm{Bu}$ tip insanlar kendi bireyselliklerinin olduğu kadar bir sistemin parçası olduklarının farkındadırlar. Kişiler, aile, okul, organizasyonlar ve takımlar gibi kendilerinden daha büyük bir oluşumun bir parçası olduklarını bilirler. Bir okul ortamında öğretmenler özerk bir şekilde karar alabilirler, ancak daha büyük bir sistemin parçası olarak karar alırken, kararlar sistem kültürünü ve oradaki insanları etkiler. Bilişsel koçluk bu süreç için bir dayanak teşkil eder (Reed, 2006, s.43).

Bilişsel koçluğun bir amacı da kişinin eşzamanlı olarak bir parça ve bütün olma durumu olarak da tanımlanabilen holonomiye ulaşmasıdır (Costa ve Garmston, 2002, s.122- 123). Etkili öğretmenler kendini savunan, motive eden, değiştiren özerk bireylerken aynı zamanda daha büyük bir bütün olan bir bölümün, okulun ya da bir bölgenin de parçası durumundadırlar. Toplumun değerlerinden, tutumlarından, davranışlarından ve kurallarından etkilenirler. Holonomi kavramı çevresinde hem parça hem bütün olma bazı ikilemleri de yanında getirir. Bu çelişkili durumları etkili bir şekilde dengelemek ve çözüme kavuşturmak için iç kaynaklar geliştirmek gerekir. Bu iç kaynaklar beş zihin durumuyla açılanabilir (Costa ve Garmston, 2002, s.123- 124). Henry'e (2012, s.31) göre bu beş zihin durumu bilişsel koçluğun merkezindedir ve hem bireysel hem de toplu olarak işe yararlar. Koçluğun merkezinde bu denli önemli olan zihin durumlarını incelemek gerekir.

\section{Zihin Durumları}

\section{Etkinlik/Yeterlik}

Yeterlik zihin durumlarının temelini teşkil etmektedir. Bireylere dünyayı değiştirme gücünü veren motivasyon, umut ve kendi yeteneğine karşı duyduğu inancın da kaynağıdır (Ellison ve Hayes, 2009). Bandura (1997) öz yeterliği, kişinin eğitim ortamında arzu edilen kazanımları ortaya koymak için kendi davranış değişikliği oluşturma yeteneğine duyduğu inanç olarak tanımlamıştır. Eğitim ortamında yeterlik ise öğrenme ortamlarını etkilemek için bireylerin yeterli bilgi ve yeteneğe sahip olmasını gerektirmektedir. Bu şekilde bireyler arzu edilen kazanımları edineceklerdir (Ellison ve Hayes, 2009). Etkili/yetkin insanlar her işin üstesinden gelmektedirler. Gelecek eylemleri doğru bir şekilde tahmin edip,. iyimser ve kendilerinden emin bir tavır sergilemektedirler. Kendilerini iyi tanır ve öfkelerini başarılı bir şekilde kontrol edebilirler. Yeterlik beş zihin durumu içinde katalizör görevi görenidir. Çünkü bu özellik kişinin karşılaştığ1 karmaşık bir problemi nasıl çözeceğine karar vermesinde temel teşkil eden bir faktördür. Yeterli öğretmenler enerjilerini işlerine sarf eder ve zorlayıcı amaçlara ulaşmaya çalışırlar (Costa ve Garmston, 2002, s.126-127) . Ellison ve Hayes de (2009) yüksek derecede yeterliğe sahip öğretmenlerin eğitim ortamlarında yaptıkları uygulamalarla öğrenmeye aynı derecede katkı sağlayacağını bir başka değişle öğrencinin kesin olarak öğreneceğini savunmaktadırlar.

Edwards ve Newton (1995, s.6-7) yaptıkları çalışmada da bilişsel koçluğun amaçlarından birinin öğretmenlerin etkinliğinin artırılması olduğunu belirtmiş ve çalışmalarında Gibson ve Dembo (1984)'nun yaptığı çalışmaya atıfta bulunarak etkinlik özelliğine düşük oranda sahip olan öğretmenlerin öğrencilerin sorularını diğer öğrencilerin cevaplamalarını isterken yüksek derecede yetkin öğretmenler öğrencilerin sorularını kendi sorularıyla yönlendirip, onları cevaba ulaştırdıklarını ifade etmişlerdir. Yeterlik üzerine yapılmış bir çalışma birbiriyle bağıntılı bazı bulgulara ulaşmıştır (Tschannen-Moran, Woolfolk Hoy ve Hoy, 1998): 
- $\quad$ Yeterlik kendini gerçekleştiren bir olgudur. Yeterlik arttıça öğretmenler daha fazla çaba gösterip daha iyi sonuçlar alırlar; yeterlik azaldıkça ise öğretmenlerin çabaları ve alınan sonuçlar da aynı oranda azalacaktır.

- $\quad$ Yeterlik öğrenmeyi destekleyecek yeni fikirlere ve deneyimlere açık olmaya yol açar.

- $\quad$ Yeterlik zorluklar karşısında gösterilecek direnci ve istekliliği artırır.

- Yeterlik başarısızlık karşısında öğrenciyi sorumlu tutup eleştirme durumunu azaltıp, öğretmenleri mevcut planlarını gözden geçirmeye teşvik eder.

- $\quad$ Yeterlik öğretmenin öğretim şevkini artırır.

- $\quad$ Okul düzeyinde yeterlik sağlıklı bir örgütsel iklimi destekler.

- $\quad$ Okul düzeyindeki yeterlik düzenli be olumlu bir öğrenme ortamı yaratıp ögretim ile ilgili kararların sınıf bazında alınmasını destekler.

\section{Bilinç}

Bilinç, öz farkındalığa neden olup bu şekilde diğer zihin durumlarını gözden geçirmeye olanak sağlar (Ellison ve Hayes, 2009). Costa, Garmston, Saban, Battaglia, and Brubaker (2003, s.128) ise bilinci kişinin kendisini gözlemleme ve yansıtma kapasitesi olarak tanımlar ve bilinç durumunun kişisel gelişim için bir kaynak olduğunu ve bu durumun kişiyi diğer canlılardan ayıran bir özellik olduğunu savunurlar. Bilinçli olmak durumu kişinin kendi üstbilişine hâkim olmasını gerektirir. Yüksek bilinç düzeyine sahip insanlar kendi iç seslerini dikkatlice dinlerler. Başkalarıyla çalışma durumunda da önyargıların kendilerine engel teşkil ettiğinin farkındadırlar(Ellison ve Hayes,2009). Bilinçli olmak Costa ve Gamrmston'a (2002, s.135-138) kişinin düşüncelerinden, duygularından, bakış açılarından ve davranışlarından ve bunların kendisi ile başkaları üzerindeki etkilerinden haberdar olmasıdır. Bilinç diğer zihin durumları arasında arabuluculuk yapacak olan araçtır. Bilinç diğer zihin durumlarının her biri için gözlemleme bölgesidir.

Yüksek düzeyde bilinç sahibi insanlar kendi iç seslerinin dinleyerek kendi düşünme süreçlerini izlerler. Bu süreçte kendilerine sordukları sorular aşağıdaki gibidir (Ellison ve Hayes, 2009):

- $\quad$ Mantıklı mi, duygusal miyım?

- $\quad$ Mevcut durumla ilgili sahip olduğun ön bilgiler şu anki düşünce sürecimi ne ölçüde etkilemektedir?

- Ne tür yargilarda bulunurum?

- Mevcut durumla ilgili farklı bir bakış açısına nasıl sahip olabilirim?

Özüne gösterdiği ilgiye ek olarak bilinçli insan dış belirtileri de dikkatle takip eder. Zira sınıf içindeki her deneyimin iki düzeyi vardır. Biri kişinin özüne, diğeri ise kendisi dışındakilere gösterdiği ilgidir. İkisine aynı anda ve aynı seviyede ilgi göstermek ise oldukça gelişmiş bir bilinç düzeyinin işaretidir. Bunun dışında bilinçli bir insanın geçmiş ve bugün ile de sürekli bağlantı kurması gerekir. Bu durum da halihazırda insani diğer canlılardan ayıran özelliğidir (Damasio, 1994).

\section{Hüner}

Kişinin kendi başarılarıyla ilgili hissettiği sağlıklı bir memnuniyetsizlik hissidir. Hüner bu hisleri düzeltir ve sürekli olarak gelişmeleri için çalışır (Costa ve Garmston, 2002). Bir başka tanımla hüner kişileri bireysel bazda ve grup bazında mükemmeliyete yönlendiren bir dürtüdür. 
Kişilerin performanslarını belirli bir standartla ölçmekten ziyade daha yüksek standart arayışında olma durumudur (Ellison ve Hayes, 2009). Hünerli bir kişi (Costa ve Garmston, 2002):

- Kendi performansını ve sonuçlarını değerlendirir.

- Bilgi arayışında olmaya değer verir ve edindiği bilgiyi çalışmak ve gelişmek için kullanır.

• Kendisi için yüksek standartlar belirler.

• Görünüşte çalışmaları basit olsa da karmaşık bir sürecin ürünüdür.

-Amaçlarına ulaşmak için gelişimlerini gözlemler ve düzeltirler.

- Devamlı gelişim yolunda çabalarlar. çalışırlar.

- Olan ve olmasını istedikleri durumlar arasında boşluğu kapatmaya

-Zaman kontrolünde iyidirler.

Hüner sahibi bir öğretmen ise öğrenim sürecindeki durumların hangi sırada ve ne kadar sürede gerçekleşeceği, hangi hızla ilerleyeceği, aynı anda gerçekleşecek durumlarda ne yapılacağı, kiminle ve neyle eşzamanlı çalışılacağı ve kısa ve uzun süreli bakış açılarının ne olduğu konularını yönetmekte ustaca davranan kişidir (Costa ve Garmston, 2002, s.134). Hünerli bir öğretmen her zaman için öğrencilerinden beklentisini çok yüksek tutar. Yeni hedefler koymadan mevcut durumu detaylıca analiz ederek aksaklıkları tespit eder. Yargılardan ve eleştiriden kaçınır ancak sürekli devam eden bir öz-değerlendirme süreci içindedir. Sürekli devam eden öz-değerlendirme de kişilerin performanslarını ve başarılarını geliştirip artırmaktadır (Ellison ve Hayes, 2009). Özetlemek gerekirse hüner durumu kişinin mükemmele ulaşmak için izlediği yoldur denilebilir.

\section{Esneklik}

Esnek insanlar birden fazla bakış açısına sahip, değişime açık, yeniliklere çabuk uyum sağlayan kişilerdir. Esneklik kişinin kendisinden öteye gidip, olaylara farklı perspektiflerden bakabilmesidir. Esneklik yaratıcı problem çözmeyle yakından ilişkilidir. Esnek bir öğretmen her bir deneyime öğrenme fırsatı gözüyle bakan ve karşılaştığı problemleri çözmekten hoşlanan kişidir. Etkililik gibi esneklik de risk almayı gerektirir (Costa ve Garmston, 2002, s.129-132). Esneklik ben merkezcilik eğiliminin ötesine geçmeyi sağlar. Esnek bir öğretmen olaylara farklı açılardan bakmaya açıktır. (Ellison ve Hayes, 2009, s.77). Henry (2012, s.34)'ye göre esnek öğretmenler çıkmaza girdiklerinde bu durumdan kurtulmak için fikir üretebilme ve birçok seçeneği ya da kaynağı kullanabilme yeteneğine sahiptirler. Olaylara farklı açılardan bakabilmek esnek öğretmenlere bakış açıları arasında hızlıca değişim yapabilmeyi sağlar. Wheatley'in de (2005) belirttiği üzere bizi ayıran farklılıklarımız değil; yargılarımızdır. Merak ve karşıdaki kişiyi iyi dinleyip analiz etmek bizleri tekrar bir araya getirecektir.

Esneklik aynı zamanda yaratıcılık ve problem çözme için de bir mihenk taşı olarak kabul edilmektedir. Zira, esnek bir insan farklı alternatifler, bakış açıları ve olasılıklar keşfetmeye çalışır; ayıplamak ve suçlamak yerine farklı davranışlar denem eğilimindedir (Ellison ve Hayes,2009).

\section{Karşılıklı Bağımlılık}

Kişiler karşıllklı aidiyet ve bağlanma ihtiyacı duyarlar. Hem tek hem de daha büyük bir sistemin bir parçası olma eğilimindedirler. (Costa ve Garmston, 2002, s.139). Karşılıklı bağımlılık insanların tek başlarına ben-merkezli olması ve aynı zamanda bütünün de bir parçası olması durumudur. $\mathrm{Bu}$ durumda bu ilişki içindeki insanlar ben merkezcilik (egocentricity), diğer merkezcilik (allocentricity) ve de sistem merkezcilik (macrocentricity) arasında dolanırlar. 
Kendilerinin sisteme; sistemin de kendilerine olan ihtiyacının farkındadırlar (Ellison ve Hayes, 2009). Her sistemin merkezinde bireylerin birbirine ihtiyaç duydukları farkındalığı yatmaktadır. Bu nedenle tüm sistemlerde işbirliği ayakta kalmak için gereklidir (Wheatley, 2005). Karşılıkl1-bağımlı insanlar (Costa ve Garmston, 2002, s.140-141):

- Toplumsallık duygusuna sahiptirler.

- İmece yapmaya önem veririler ve grup amaçlarını gerçekleştirmeye çalışırken prensipli bir yol izleyerek kendi inançlarına sadık kalırlar.

- $\quad$ Grup içerisinde kaynak arayışındadırlar. arayacaklarını bilirler.

- Grupla hangi noktada birleşeceklerini hangi noktada kendi haklarını

- $\quad$ Kamu menfaati için hizmet verirler.

- $\quad$ Çelişkiyi; bir öğrenme kaynağı, problem çözme firsatı ve toplumun diğer yüzü olarak görürler.

- $\quad$ Tüm ilişkilerde holonomi ararlar çünkü birlikte tek olduğundan daha etkili olunduğunun bilincindedirler.

Öğrenci başarısını artırmak için işbirliği kültürünü oturtmak gerekmektedir. Bunun için etkili eğitimciler hiyerarşik olarak örgütlenmiş otoriter bazlı sistemlerden öteye hareket etmelidir. Bunu yapabilmek için de öğrenciye, okula ve sisteme eşit ve karşılıklı bağımlılık duygusuna sahip olmak gerekmektedir (Ellison ve Hayes, 2009).

Costa ve Garmston'a (2002, s.141) göre ideal durum olan holonomiye tam anlamiyla ulaşmak imkânsızdır. Ancak amaç holonomiye ve beş zihin durumuna yolculuk etmektir. Eğitimcilerin amacı öğrencilere en iyi öğretimi sağlayacak zorluklara sahip olmaktır. Çünkü amaç; sözü edilen sistemde kendi değerlerine sahip, zekâlarını kullanabilen ve özerk bireyler yetiştirmektir. Bilişsel koç bu beş zihin durumunu bir araya getirecek stratejilere sahip olmalıdır.

\section{Bilişsel Koçluk Görüşmeleri}

Bilişsel koçluk bilişsel gelişimi sağlayan zihinsel bir modeldir. Bu modelde takip etmesi gereken zihin haritaları mevcuttur. Nasıl ki bir alanı keşfetmek için sembolik temsil aracı olarak haritalara ihtiyaç duyulursa zihnin de aydınlanması, keşfedilmesi gereken yerlerine yolculuk yapmak için bilişsel koçluk haritalarına ihtiyaç duyulmaktadır. Bu haritalar yazılı belgelerden ziyade zihnine yolculuk yapılacak olan kişinin düşünme sistemidir (Ellison ve Hayes, 2009). Bilişsel koçun kullanacağı uygulama çerçevesinde üç görüşme haritası tanımlanmaktadır. Bunlar Costa ve Garmston (2002, s.34)'e göre

\section{Planlama Görüsşmesi}

Bilişsel koç bu evrede karşısındaki kişiyi bir olaya katılmadan bir zorluğun üstesinden gelmeden ya da bir göreve başlamadan önce aydınlatır ve kişiye bilişsel planlama sürecinde yardım eder. 


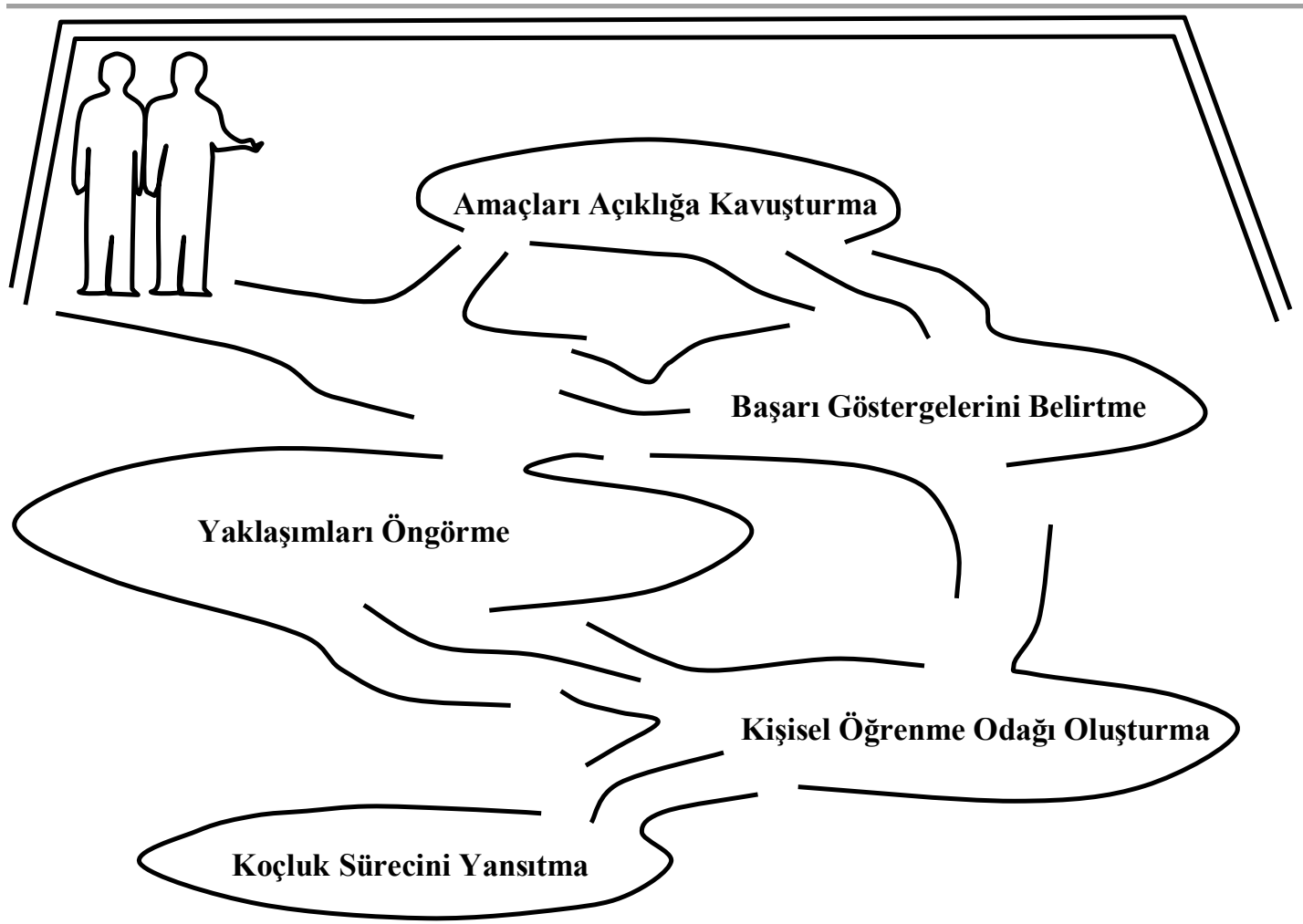

Şekil1. Planlama haritası (Costa, 2002, s.36).

Planlama görüşmesinin bölgeleri yukarıdaki mantıksal sırada koçun zihninde belirir. Ancak kişi ilgileri ve düşünme sürecine bağlı olarak bölgeleri istediği sırada ziyaret edebilir. Planlama görüşmesinin her hangi bir bölümünde koç ya da destek alan kişi bir bölgeyi daha ziyaret etmek isteyebilir (Costa ve Garmston, 2002).

$\mathrm{Bu}$ haritanın iki odağı bulunmaktadır. Odaklardan biri eylemin diğeri de planlamayı yapan kişinin üzerindedir. Haritadaki ilk üç bölge eylemin üzerine odaklanmaktadır. Bu kısımda planlamacı zihinde eylemi prova eder. Bu şekilde eylemin beklenen sonuçları ve değerlendirme şekilleri zihninde netliğe kavuşur. Koçluk alan kişi bu ilk üç bölgede etkili stratejileri tahmin eder ve eylem ilerleme sürecini gözlem yolları belirler. Haritanın en can alıcı bölgesi olan dördüncü bölgede bireyin odağı eylemden kendi özüne döner. Bu bölgede koçluk alan kişi profesyonel öğrenme amacını net olarak oluşturmuştur. Bu bölge kişisel profesyonel gelişimin ve deneyimleri anlamlandırmanın oluştuğu yerdir. Bu kısım atlanırsa görüşmeler sığ kalacaktır. Haritadaki en son alan yansıtma alanıdır. Koçluk alan kişi tüm görüşmelerin sentezini yapar ve koça geri bildirim verir (Ellison ve Hayes, 2009). Bir bașka ifadeyle koç ve destek alan kiși düşünme ve karar vermedeki etkilerini açığa çıkarmak ve gelecekte yapılacak planlama görüşmeleri için tavsiye niteliği taşıması adına tüm görüşme alanını yansıtırlar (Costa ve Garmston, 2002).

\section{Yansıtma Görüssmesi}

Bir yansıtma süreci olan kendini keşfetme öğrenme alışkanlığı olarak koçluk esnasında yapılır. Kendini keşfetme kişiyi hem duyuşsal hem de bilişsel seviyeye ulaştıran bir süreçtir. (Costa ve Garmston, 2002). Zira bu görüşmeler koçluk alan kişiye deneyimlerini analiz etme ve onlardan bir şeyler öğrenme fırsatı yaratır. Bu durum bir başka deyişle gelecekteki öğrenme yaşantılarının da dönüştüğü alandır. Yansıtma yapmadan kişiler davranışlarındaki eksikliklerin farkına varmadıklarından yaptıkları davranışlar mükemmelmiş düşüncesiyle onları tekrar ederler. 
Yansıtma görüşmeleriyle dönüşen eylemler sayesinde koçluk alan kişi zihninde genellemelere ulaşır. İnsan beyni de spesifikten ziyade genel olanı hatırlama eğiliminde olduğu için bu işlem insan beyni ile de uyum içindedir (Ellison ve Hayes, 2009). Bu görüşmenin beş bölgesi bulunmaktadır. Bu bölgelerin her biri özel amaçlarla ziyaret edilir. Herhangi bir sirayla ziyaret edilebilecek bu bölgelerden 'izlenimleri özetleme' bölgesi genellikle gidilecek ilk bölgedir. Bu bölgede yaşanan deneyim tekrar canlandırılır. $\mathrm{Bu}$ canlandırma sirasında muhtemelen olay esnasında hissedilen duygular geri çağırılır. 'Nedensel faktörleri çözümleme' bölgesinde planlanmış ve gerçekleşmiş sonuçlar karşılaştırılır. Sonuçları ortaya çıkaran faktörler ve eylem esnasında alınan kararlar yorumlanır. 'Yeni öğrenmeyi yapılandırma' bölgesinde amaç çözümleme ardından anlam çıkarma ve planlama görüşmesi sırasında tanımlanan kişisel öğrenmelerin sentezi yapılır. Genellikle yansıtma öncesi ziyaret edilen son bölge olan 'İcra etme' bölgesinin amacı ise gelecek öğrenmeler için başvuruda bulunmak, diğer yaşam koşullarına köprü olma, öğrenilen bilgileri transfer etme ve kişisel davranış değişimlerini öngörmedir. Koçluk süreci yansıtılırken öğrenme yolculuğunun tamamlanmasının ardından koç partnerini tüm görüşme üzerinde yansıtma yapmaya davet eder (Costa ve Garmston, 2002, s.39-40).

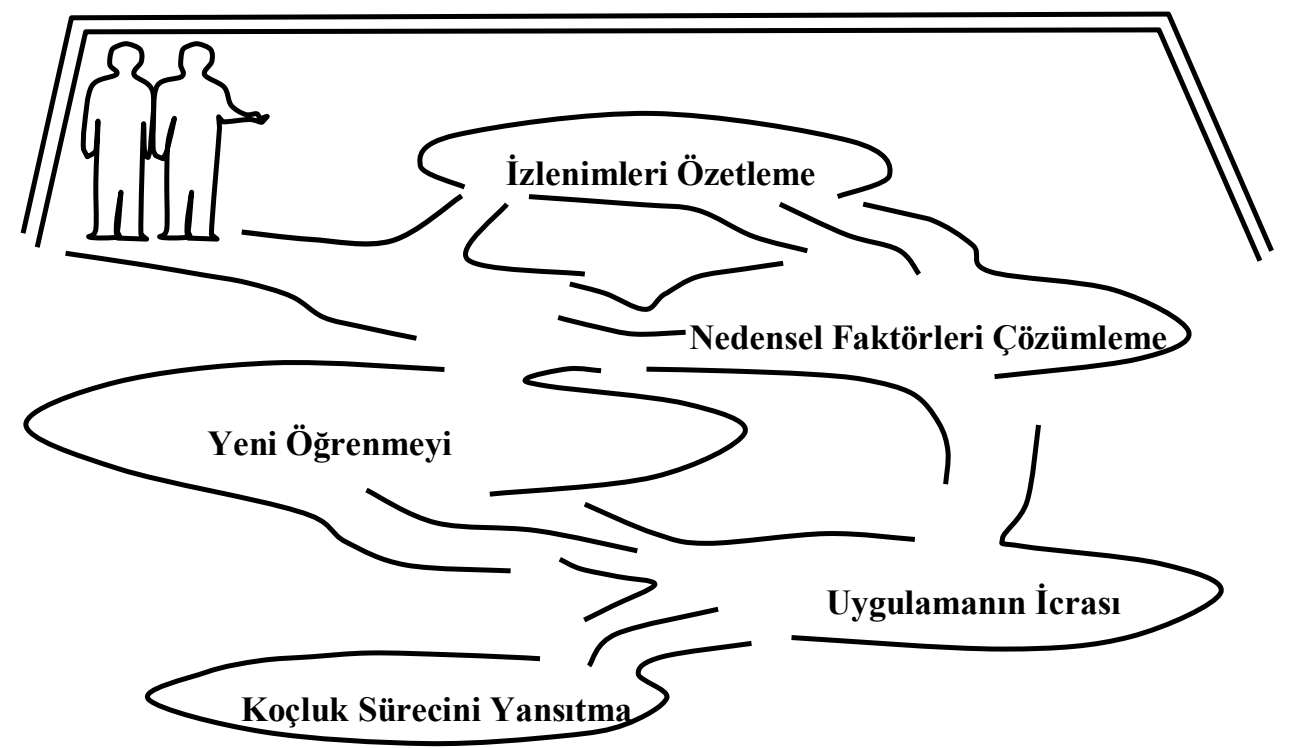

Şekil2. Yansıtma haritası(Costa, 2002, s.41).

\section{Problem Çözme Görüş̧mesi}

Bu görüşme kişi kendisini çıkmazda, çaresiz, belirsiz ya da beceriksiz hissettiğinde; bir kriz yaşadığında ya da desteğe ihtiyaç duyduğunda yapılır. Diğer görüşmeler arasında en karmaşık olan problem çözme görüşmesinde kişi problemini söyler ve koçla birlikte problemin muhtemel sebeplerini ortaya çıkarmaya çalışırlar (Costa ve Garmston, 2002). Var olan durum, yani koçluk alacak kişinin mevcut gerçeği açıkça tanımlanır. Bu durum kişinin duygusal durumunun açıklığa kavuşması için önem arz etmektedir. Bilişsel koç hem olaya hem de kişinin duygularına odaklanır (Ellison and Hayes, 2009). Daha sonra alternatif yaklaşımlarıyla problemin çözüme kavuşacağı ulaşmak istedikleri durumu zihinlerinde canlandırırlar. Problemli durum belirsizdir ve kişi beş zihin durumunu sınırlı bir şekilde kullanmaktadır. Ancak problem çözme görüşmesi yoluyla ulaşı1mak istenen durum nettir ve çözüme zihnin beş durumu kullanılarak ulaş1lır. Problem çözme sürecinde kullanılan 'adım at ve yol göster' modeli ile kişi var olan durumdan ulaşılmak istenen 
duruma giderken koç ona yol gösterir ve eşlik eder (Costa ve Garmston, 2002, s.191-195) Bu görüşmeler sorunların ya da deneyimlerin içeriklerine göre bilişsel koçluk çerçevesinde şekillenir.

Yetenekli koçlar bu haritaları uygularken esnek davranabilirler. Koçluk alan kişinin ihtiyaçları, duygu durumu ve tutumu haritanın hangi alanının öne çıkacağına; hangisinin ise atlanacağına karar verilmesinde göz önünde bulundurulur (Ellison ve Hayes, 2009). Zaman ve durum uygun olursa bilișsel koç koçluk döngüsünün bütününü uygulama firsatı yakalayabilir. Aşağıdaki koçluk döngüsü diyagramı amaçları belli, eylemleri gerçekleşen, bulguları gözlenen, toplanan ve yorumlanan ve devamında yeni amaçların belirlendiği devamlı bir öğrenme sürecini tarif etmektedir (Costa ve Garmston, 2002).

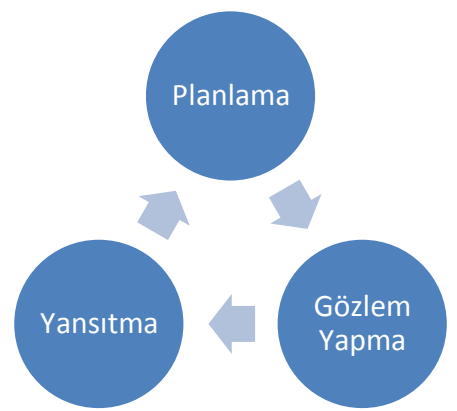

Şekil3. Koçluk Döngüsü (Costa ve Garmston, 2002, s.43).

\section{Bilişsel Koçun Süreçte Kullandığı Dört Temel Araç}

Bilişsel koçun arzu edilen güven ortamını yaratabilmesi için iletişim becerilerini etkili bir şekilde kullanması gerekmektedir. Bilişsel koç öyle rahat ve güvenli bir ortam yaratmalıdır ki koçluk alan kişi koçun tamamıla orada olduğunu ve dikkatle kendisine odaklandığını hissetmelidir. Bilişsel koç karşısındakini dinlerken sözel ve sözel olmayan becerilerini kullanır. Zira koçun amacı danışanının düşünebilmesi için optimal koşulları oluşturmak olmalıdır (Ellison ve Hayes, 2009). Becerikli bir koçun danışanının bilişsel gelişimi için kullandığı araçlar dört temel grupta açıklanabilir. Bunlar: sözsüz iletişim, tepki davranışları, yapılandırma ve aracılı sorgulamadır (Costa ve Garmston, 2002).

Sözsüz iletişim; kullanılan sesin niteliği (tonlama, konuşma hızı, ahengi), beden dili (jest ve mimikler), duruş, dil seçenekleri, nefes alma, başka birçok sözel olmayan davranış1 kapsamaktadır. (Costa ve Garmston, 2002). Swanson (1995) çalışmasında yetişkinlerin sözel yerine sözel olmayan davranışlardan daha fazla anlam çıkardıklarını ortaya koymuştur.

Tepki davranışları ortama ve koçluk alan kişiye göre değișiklik göstermektedir. $\mathrm{Bu}$ davranışlar; sessizlik, onaylama, başka sözcüklerle anlatma, netleştirme ve bilgi ve kaynak sağlama şeklindedir. Sessizlik esasında verimli bir iletişimin göstergesi olarak kabul edilir. Zira soruyu sorduktan ya da cevabı aldıktan sonraki sessizlik karşıdaki kişinin yansıtma yapabilmesi için ona gösterilen saygıdandır (Costa ve Garmston, 2002). Ellison ve Hayes de (2009) sessizliğin daha üst düzey bilişsel işleyiş için gerekli olduğunu ve de hem koç hem de koçluk alan kişinin düşünmesi için zaman yaratması noktasında gerekli olduğunu ifade etmiş̧lerdir. Onaylama, karşıdaki kişiyi yargılamadan söylediğini olduğu gibi kabul etmedir ve iletişimi kolaylaştırır (Costa ve Garmston, 2002). Söyleneni farklı sözcüklerle ifade etme iletişimde temel araçtır. Bilişsel koç bu tekniği danışanı kendi hislerini başka bir ifadeyle başkasının ağzından duysun ve tekrar değerlendirsin diye kullanır (Ellison ve Hayes, 2009). Bu teknik çok iyi dinleme ve gözlemleme gerektirir (Costa ve Garmston, 2002). Netleştirme, koçun belirsiz durumları açıklığa kavuşturmak için kullandığı bir 
davranıştır (Costa ve Garmston, 2002). Bilişsel koç danışanıyla kurduğu iletişim sonucunda çok net bir resme sahip olmak ister. Bu durumda da danışanın tüm ifadelerinin net olması gerekir (Ellison ve Hayes, 2009). Bilgi ve kaynak sağlama davranışı bilişsel koçluk sürecinde önemli bir işleve sahiptir. Koçluk alan kişi bir öğretmense koçtan kendisini ders esnasında kaydetmesini ve bu şekilde ona kayıtlı bir veri sağlamasını talep edebilir. Koçluk davranışı içindeki bu veri sağlama davranış1 objektif olmalıdır (Costa ve Garmston, 2002).

Yapılandırma, koçun danışanının ihtiyaçlarını tam olarak tespit edip ona destek olacağ 1 durumları ortaya koyduğu araçtır. Bilişsel koç sözel olarak danışanının isteklerini ve uygulayacakları programı netleştirip programı yapılandırır (Costa ve Garmston, 2002).

Aracılı sorgulama için sorular karşıdaki kişinin düşünme sistemini ve bakış açısını değiştirmek için tasarlanır. Bu sorular en az üç kriteri karşılamalıdır:

- Biçim ve tonlama açısından davetkar olmalı,

- $\quad$ Özel ve karmaşık bilişsel süreçleri kullanmaya olanak vermeli,

- Hem çevresel hem de duygusal ve zihinsel içeriğe işaret etmelidir (Costa ve Garmston, 2002).

Kısaca, bilişsel koçlar amaçları doğrultusunda danışanlarının bilişsel kapasitesini güçlendirmek ve kişisel gelişimine katkıda bulunmak için yukarıda açıklanan sözel ve sözel olmayan araçları maksatlı olarak kullanırlar.

\section{Bilişsel Koçluk Çalışmaları}

Bilişsel koçluk alanında yapılan araştırmalar incelendiğinde, bilişsel koçluğun genellikle öğretmen eğitimi alanında ve öğretmenler üzerindeki etkilerinin incelendiği görülmüştür. Ancak şimdiye kadar anlatılanlardan yola çıkılırsa bu uygulamaları öğrenciler üzerinde de denemek etkili olacaktır. Başka bir ifadeyle öğretmenliğin koçluk desteğine ihtiyacı olduğu kadar öğrencilerin de koçluk desteğine olan ihtiyaçları açıktır. Jenny Edwards da (2004, s.1) yaptığı sentez çalışmasında şimdiye kadar bu konuyla ilgili yapılmış çalışmaları incelemiş ve bu hususta bilişsel koçluktan beklenen dokuz sonucu şu şekilde sıralamıştır:

1. Öğrencilerin sınav skorlarında yükselme ve öğrencilerin yararlanabileceği diğer yönler,

2. Öğretmen etkililiğinde artış,

3. Öğretmenlerin yansitıcı ve girişik düşüncelerinde artış,

4. Öğretmenlerde pozisyon ve kariyerleri noktasında memnuniyet,

5. Okulda profesyonel bir ortam sağlanması,

6. $\quad$ Öğretmenlerin birbirleriyle daha sık işbirliği içerisine girmeleri,

7. Öğretmenlere sağlanan profesyonel destekte artış,

8. Öğretmenlerin kişisel olarak bu süreçten olumlu olarak etkilenmeleri,

9. Öğretim alanının dışında da insanların da bu uygulamalardan faydalanmaları

$\mathrm{Bu}$ sonuçları ortaya koyan çalışmaları sonuçları bazında alt başlıklarla incelemek alandaki boşlukları tespit edebilmek noktasında önem arz etmektedir. 


\section{Bilişsel Koçluk Uygulamalarının Öğrenciler Lehine Elde Edilen Sonuçları}

Üç farklı ilkokul öğretmeni bilişsel koçluk desteği aldıktan sonra öğrencilerinin daha derin düşünme kapasitesine eriştiği tespit edilmiştir.(Gonzales Del Castillo 2015). Öğretmene soru sorma şekillerini değiştirmeye yönelik uygulanan koçluk neticesinde öğretmenlerin öğrencilere açık uçlu sorular sorarak onları daha karmaşık düşünmeye sevk ettikleri kaydedilmiştir(Irons, 2014). Öğretmenlerin aldıkları bilişsel koçluk uygulamalarının ardından öğrencilerin öğrenmelerindeki yerlerini sorguladıkları bu yolla da öğrencilerin öğrenmelerini kolaylaştırdıkları görülmüştür (Jaede vd.,2014). Yürütülen bir başka önemli araştırmada öğretmenleri 4 ay boyunca bilişsel koçluk seminerlerine katılmış olan öğrencilerin okuma derslerinde akademik başarılarının öğretmenleri koçluk almayanlara göre daha yüksek olduğu ortaya konmuştur (Diaz, 2013). Matematik dersindeki öğrenci başarısının arttığını araştıran bir çalışmada bilişsel koçluk desteği alan öğretmenlerin öğrencilerine bilişsel koçluğa dair 5 zihin durumunu ve her durumda nasıl düşünmeleri ve problemleri çözebileceklerini öğrettikleri gözlemlenmiştir (Rinaldi, 2013). Matematik başarısının arttı̆̆ını gözlemleyen bir diğer çalışmada da bilişsel koçluk desteği alan öğretmenlerin öğrencilerinin problem çözme becerilerinin geliştiği görülmüştür (Ushijima 1996). Bilişsel koçluk desteği alan öğretmenlerin öğrencilerle daha etkili etkileşim kurdukları ve öğrencilere duygusal ve öğretimsel alanda daha fazla destek olabildikleri aynı zamanda sınıf düzeninde de etkili oldukları gözlemlenmiştir (Lin, 2012). Koçluk desteğinden sonra, öğretmenlerin öğrencilerin bireysel farklılıklarına ve ihtiyaçlarına karı daha hassas oldukları ve de bu ihtiyaçları karşılamak üzere adımlar attıkları belirtilmiştir (Robinson, 2011). Öğrencilere bilişsel koçluk eğitimi verildikten sonra birbirlerine koçluk yapmaları istenmiş ve yazı derslerinde kendilerine güvende ve düşünme becerilerinde gelişme olduğu sonucu ortaya çıkmıştır (Powell ve Kusuma Powell, 2007). Bilişsel koçluk desteğiyle öğretmenlerin öğretimlerinde bir dönüşüm olduğunu belirten bir çalışmanın sonuçları arasında öğrenci-öğretmen ilişkilerinde olumlu değişme ve de öğrencilerin problem çözme becerilerinde artış saptanmıştır (Eger 2006).Düşük performanslı okulların öğretmenlerine yapılan bilişsel koçluk uygulamalarının öğrencilerin özellikle okuma becerilerini geliştirdiği kanıtlanmıştır (Fine ve Kossack, 2002). Anaokulu öğretmenlerine verilen bilişsel koçluk desteği ile ilk okuma becerisini kazandırma yeteneği arasında pozitif bir ilişki tespit edilmiş koçluk alan öğrencilerin öğrencilerinin daha rahat okumaya geçtiği görülmüştür (Rennick 2002). Koçluk alan öğretmenlerin öğrencilere kendilerine dair kararları özerk bir şekilde almalarını öğreten öğretmenlerin sınıflarında güven ortamı ve önyargısız tutum oluşturdukları görülmüştür (McLymont 2000, McLymont \&Costa, 1998). Üniversite düzeyinde yapılmış bir çalışmada da bilişsel koçluk alan profesörlerin öğretim alanlarını genişletirken öğretim dillerinin daha anlaş1lır ve sade hale geldiği gözlemlenmiştir (Garmston \& Hyerle, 1988). Çalışmalar

Bilişsel Koçluk Uygulamalarının Öğretmenlerin Etkinliğini Artırdı̆̆ını Ortaya Koyan

Bilişsel koçluk uygulamalarıyla öğretmenlerin öğretimlerinde etkililiğin arttığını (Wooten Burnett 2015, Robinson, 2011, Maginnis, 2009; Edwards vd.,1998; Edwards \& Green, 1997;Krpan 1997; Smith, 1997; Edwards \&Newton, 1995) ortaya koyan çalımalar olduğu gibi; profesyonel anlamda gelişim planlarına karşı daha olumlu tutumlara sahip olduklarını belirten (Edwards \&Green, 1997) ve de zihin durumlarını da daha etkin kullandıklarını belirttikleri (Alseike 1997) çalışmalar yapılmıştır.

\section{Bilişsel Koçluk Uygulamalarının Öğretmenlerin Düşünme Becerilerini Özellikle de Yansıtıcı Düşünme Becerisini Geliştirdiğini Kanttlayan Çalışmalar}

Bilişsel koçluk uygulamalarıyla öğretmenlerin eylem üzerine yansıtma becerilerinde gelişme olduğunu kanıtlayan çalışmalar (Chang, Lee \& Wang 2014; Bjerken, 2013; Diaz, 2013; Henry, 2012; Lin, 2012; Loeschen, 2012; Robinson, 2011; Eger, 2006; Evans, 2005; Slinger, 2004; McLymont, 2000; McLymont\& Costa, 1998; Edwards, Green, 1999) olduğu gibi duygusal zekay1 
artırdığını (Avant, 2012), değerlendirme, analiz ve sentez yapma becerilerinde artı̧̧ olduğunu (Eger, 2006; Foster,1989; Alseike, 1997), daha karmaşık düşünce süreçleri edindiklerini (Edwards, 1993), beyinlerinin sağ kısmını daha çok kullanarak analitik ve sezgisel yeteneklerini kombine ettikleri (Garmston, Linder\& Whitetaker, 1993) ortaya koyan çalışmalar da yürütülmüştür.

\section{Bilişsel Koçluk Uygulamalarının Öğretmenlerin Mesleki Tatminlerine İlişsin Çalışmalar}

Yapılan uygulamalar ve alınan görüşler neticesinde öğretmenlerin bilişsel koçluk uygulamaları sayesinde mesleki tatmin duygusuna ulaşabileceklerini hissettikleri (Edwards vd.,1998; Awakuni, 1995; Edwards \&Newton, 1995; Edwards,, Newton, 1994, Edwards, 1993) eğitim alanında motivasyonlarının yükseldiğini ifade ettikleri (Edwards \&Newton, 1994) ve de ögretmenlik mesleğinde zevk almaya başladıklarını ve bu işi şevkle yaptıklarını ifade ettikleri (Clinard, Ariav, Beeson, Minor ve Dwyer, 1995) çalışmalar yapılmıştır.

\section{Bilişsel Koçluk Uygulamalarıyla Okul Kültürünün Daha Profesyonel Hale Geldiğini Kanıtlayan Çalışmalar}

Okul yöneticilerine (Skytt, Housermann, Rogers ve Johnson, 2014) ve öğretmenlere (Knaebel 2008; Reed 2006; Eger, 2006; Dougherty, 2000; Edwards vd., 1998; Edwards ve Green 1997; Ushijima, 1996; Awakuni, 1995, Edwards \& Newton, 1994) uygulanan ilişsel koçluğun okul kültürüne geliştirici yönde katkılar sağladığı kaydedilmiştir. Bu katkılar; eğitimsel uygulamalarda değişime isteklilik (Reed 2007), diğer paydaşlarla uyum içinde çalışma ve profesyonellikte artış (Edwards vd., 1998), farklılıklara karşı saygıda ve paydaşların birbirini desteklemesinde artış (Ushijima, 1996), öğretmenler arasında işbirliği çalışmalarının arttığı ( Eger 2006; Dougherty, 2000; Edwards \& Newton, 1994) ve de bilişsel koçluk uygulamalarına dahil olan öğretmenlerin liderlik özelliklerinde gözle görülür bir artış olduğu saptanmıştır (Awakuni 1995).

\section{Bilişsel Koçluk Uygulamalarının Öğretmenlerin ve Okul Yöneticilerinin Kişisel Gelişimlerini Desteklediğini Kanıtlar Nitelikteki Çalışmalar}

Okul yöneticilerine (Rogers Hauserman ve Skytt, 2016) ve de öğretmenlere (Beltman, 2009; Edwards 2004; Mclymont, 2000; McLymont \& da Costa, 1998; Schlosser, 1998; Clinard, , 1995; Edwards\& Newton, 1994) uygulanan bilişsel koçluk eğitimlerinin onları kişisel gelişimleri bazında da desteklediği yapılan çalışmalarla kanıtlanmıştır. Özel hayatlarında da koçluk alan öğretmenlerin güven ortamı oluşturabilme ve de diyaloglarını daha rahat ve güvenli bir ortamda yürütebildikleri bununla birlikte de yaratıcılıklarında ve olaylara karşı akış açılarında esneklik olduğu belirtilmiştir (Mclymont, 2000; McLymont \& da Costa, 1998). Öğretmenlerin kendilerine güven oranlarının da arttığı sonuçlar arasındadır (Awakuni,1995; Edwards \& Newton 1994). Öğretmenlerin çevrelerindeki insanlara ve de ailelerine karşı olumlu tutumlar sergiledikleri de yapılan çalışmayla ortaya konmuştur (Clinard, vd., 1995).

\section{Bilişsel Koçluğun Öğretmenlik Dışındaki Alanlardaki Insanlara da Uygulandı̆̆ı̆ı Gösteren Çalışmalar}

Gonzalez (2009) rahipler, rahibeler ve din adamlarına master ve doktora eğitimleri esnasında 'Spiritual Accompaniment' Ruhsal Yolculukta Kişilere Refakat Etme dersi dahilinde bilişsel koçluk uygulanmış ve uygulanmamış kontrol grubu ile istatistiksel karşılaştırmalar yapılmıştır. İstatistiksel karşılaştırmalar sonucunda bilişsel koçluk kavramı dahilinde olan beş zihin durumunda ( bilinç, hüner, etkinlik, işbirliği, diğerleriyle uyumluluk) anlamlı düzeyde artış tespit edilmiştir.

Eğitimde Rönesans (Costa \& Garmston; 2002)olarak kabul edilen bilişsel koçlukla ilgili alan yazın tarandığında yukarıda yurt dışında bahsi geçen çalışmalara rastlanmıştır. Dünya genelinde çalışılan bir konu olan bu konunun Türkiye'de de çalışıldığı ve şu sonuçlara ulaştığı görülmektedir. 


\section{Türkiye’de Yapılan Bilişsel Koçluk Çalışmaları}

Tümen Akyıldız (2015) tarafindan yürütülen bir çalışmada öğrencilere yansıtıcı öğretim yönteminin yanı sıra bilişsel koçluk desteği verilmiş ve bu desteğin öğrencilerin yabancı dil öğrenim süreçlerindeki başarıyı, yansıtıcı düşünme be üstbiliş becerilerini etkileyip etkilemediği araştırılmıştır. Araştırmanın sonucunda bilişsel koçluk desteği alan grubun hem daha başarılı olduğu hem de edindikleri bilginin daha kalıcı olduğu ve de araştırılan düşünme becerilerinde de gelişme kaydettikleri tespit edilmiştir. Yapılan başka bir araştırmada, öğretmene bilişsel koçluk uygulamak yoluyla öğrencide karmaşık düşünme yeteneğinin edinildiği gözlemlenmiştir. Kıllı̧ ve Demir (2012) tarafından yapılan araştırmada ise sınıf öğretmenlerinden bilişsel koçluk ile ilgili görüş istenmiş ve öğretmenlerin literatüre yeni giren bu kavramla ilgili genel olarak olumlu görüşleri olduğu sonucu çıkmıştır. Demir ve Bal (2011) matematik öğretmenliğinde tezsiz yüksek lisans yapan öğrencilerden staj yaptıkları okullardaki matematik öğretmenlerinin bilişsel koçluk stratejilerini ne ölçüde kullandıklarıyla ilgili anketleri cevaplamalarını istemişler ve sonuç olarak bahsi geçen öğretmenlerin stratejileri derslerinde yeterince uyguladıkları çıkmıştır. Demir (2009) deneysel desenle yürüttüğü çalışmasında bilişsel koçluk yöntemi yardımıyla altıncı sınıf öğrencilinde bilişsel farkındalık becerilerini kazandırmayı, bu becerilerin kalıcılığını ve de öğrencilerin sosyal bilgiler dersindeki başarılarını ölçmeyi amaçlamış, çalışmanın sonucunda da uygulanan yöntemin bilişsel farkındalık gelişimine katkısı olurken kalıcılıkta ölçeğin birkaç boyutunda beklenen sonuca ulaşılmadığı başarı yönünden de deney grubu lehine başarı gözlemlenmiştir.

Yapılan çalışmalar değerlendirildiğinde bilişsel koçluğun destek olarak öğrencilere uygulanan birkaç çalışma (Tümen Akyıldız, Semerci 2016; Demir, 2009; Powell \& Kusuma Powell, 2007 Ushijimai 1996) dışında bilişsel koçluğun genellikle öğretmenlere ve okul yöneticilerine uygulandığ1 görülmektedir. Bu çalışmalar bilişsel koçluğun uygulandığ1 eğitim kademeleri bazında değerlendirildiğinde ise üniversite düzeyinde uygulanan birkaç çalışma dışında (Tümen Akyıldız, Semerci 2016; K1lı̨ ve Demir, 2012; Demir ve Bal, 2011 Garmston \& Hyerle, 1988) diğer çalışmaların ilk- orta ve lise derecesindeki okullarda yapıldığ 1 tespit edilmiştir. Costa ve Garmston (2000) okul liderlerinin öğretmenlere ya da öğretmenlerin öğretmenlere yaptıkları bilişsel koçluk çalışmalarının artık yeterli sayıya ulaştığını bundan sonra bu uygulamaların öğrencilere yapılması gerektiğini ve bu yolla öğrencilerin düşünme becerilerinin ve öğrenme şeklinin geliştirilebileceğini belirtmişlerdir.

\section{Sonuç ve Öneriler}

Eğitim ortamlarında sadece bilgi ve becerinin edinildiği bir öğrenme deneyiminden ziyade öğrenenin hür iradesi ve yetenekleriyle bütüncül bir gelişim göstermesi hedeflenmektedir (Stephenson, 2005). Değişimin oldukça belirgin bir şekilde hissedildiği ve eğitim ortamlarında öğrencinin özerk öğrenen özelliğiyle en ön planda tutulduğu çağımızda öğrencilere bu yolda destek vermek, onlara karmaşık düşünebilecekleri yollar açmak, yaşam boyu sürecek olan öğrenme yolculuklarında nasıl daha iyi öğrenebileceklerini öğretmek ve problem çözme becerisi kazandırmak bilişsel koçluk yardımıyla olacaktır. Bilişsel koçluğun öğretmene uygulandığı çalışmalar geride kalmış olup öğrenen merkezli ortamlarda öğrencinin gelişiminin ön planda tutulması gerekmektedir. Nitekim bazı durumlarda öğretmendeki gelişme öğrenciye tam olarak sirayet etmeyebilmektedir. Öğretmendeki gelişmenin öğrenciye etkilerini ortaya çıkarmaya çalışmaktan ziyade yapılması gereken, direkt olarak öğrencideki gelişmeyi izlemek olmalıdır. Bu durum göz önüne alındığında koçluğun tanımı kapsamında öğrencinin bilişsel koçluk yapabilen öğretmeninden ya da kendi eğitim alanı içinde olmayan birinden yukarıda bahsi geçen konularda destek alması onu yaşam boyu gelişimi noktasında destekleyecektir. Bu noktadan hareketle bilişsel koçluk yaklaşımı ilköğretim kademesinden yükseköğretime kadar farklı eğitim kademelerince, şartları düzenlemek kaydıyla uygulanabilir ve eğitimin en önemli çıktısı olan öğrencileri bilişsel ve 
kişisel yönden desteklemek noktasında kullanılabilir. Eğitim alanında yapılan araştırmalar ve iyileştirme çalışmaları başarı artırmayı hedeflemekten ziyade öğrencideki zihinsel süreçlerin geliştirilmesine odaklanmalıdır. Ancak bu sayede yaratıcı ve eleştirel düşünebilen, problem çözme becerisine sahip, bireysel olarak ve takım halinde çalışabilen ve de öğrenmeyi yaşam boyu sürecek bir durum olarak benimsemiş bireyler yetiştirilebilir. Bu bağlamda yeni yapılacak olan araştırmalarda öğrencideki başarı artışının yanı sıra bilişsel ve kişisel olarak gelişmelerinin de değerlendirilmesi gerekmektedir. Bu alanda oldukça sınırlı sayıda yapılmış olan araştırmalar artırılmalı ve kapsam olarak da geliştirilmelidir. Elde edilen bulgular bir çözüm önerisi niteliği taşıyacă̆ı için eğitim alanına yeni bir yaklaşım kazandırılabilecektir.

\section{KAYNAKÇA}

Alseike, B. U. 1997. Cognitive Coaching: Its influences on teachers (Doctoral dissertation). Retrieved from ProQuest Dissertations and Theses.

Awakuni, G. H. (1995). The impact of Cognitive Coaching as perceived by the Kalani High School core team (Doctoral dissertation). Retrieved from ProQuest Dissertations and Theses. (UMI No. 9613169)

Baker, K. L. (2008). The Effects of Cognitive Coaching on Initıally Licensed Teachers. Master Thesis. Watson School of Education University of North Carolina Wilmington.

Barkley, S. G. (2005). Quality Teaching in a Culture of Coaching. Lanham, MD: Scarecrow Education.

Beltman, S. 2009. "Educators' motivation for continuing professional learning". Issues in Educational Research, 19(3), 193-211.

Bjerken, K. S. 2013. Building self-directed teachers: A case study of teachers' perspectives of the effects of Cognitive Coaching on professional practices (Doctoral dissertation). Retrieved from ProQuest Dissertations and Theses.

Blaschke, L. \& Hase, S 2014. Heutagogy, technology and lifelong learning: curriculum geared for professional and part-time learners. In A. Dailey-Herbert (ed.), Transforming processes and perspectives to reframe higher education. New York: Springer.

Chang, D., Lee, C.-D., Wang, S.-C. 2014. "The influence of Cognitive Coaching on teaching reflection and teaching effectiveness: Taking teachers participating in formative teacher evaluation in elementary and secondary schools as examples". Journal of University of Taipei, 45(1), 61-80.

Clinard, L. M., Ariav, T., Beeson, R., Minor, L., Dwyer, M. 1995. "Cooperating teachers reflect upon the impact of coaching on their own teaching and professional life". Paper presented at the annual meeting of the American Educational Research Association, San Francisco, CA.

Cochran, B., Dechesere, J. (1995). Teacher empowerment through cognitive coaching. Thrust for Educational Leadership, 24(5), 24.

Cogan, M. L. (1973). Clinical supervision.Boston: Houghton Mifflin.

Costa, A. L., Garmston, R. J. 2002. Cognitive Coaching A Foundation for Renaissance Schools. $\left(2^{\text {nd }}\right.$ Ed.). The United States of America: Christopher-Gordon Publishers.

Costa, A. L., Garmston, R. J., Saban, J., Battaglia, A., \& Brubaker, B. (2003). Designing and constructing the holonomous school. In J. Ellison, \& C. Hayes (Eds.), Cognitive coaching: 
Weaving Threads of Learning and Change into the Culture of an Organization. Norwood, MA, Christopher-Gordon Publishers.

Damas10, A. (1994). Descartes error: Emotion, reason and human brain. New York: HarperCollins.

Demir, Ö. 2009. Bilişsel koçluk yöntemiyle öğretilen bilişsel farkındalık stratejilerinin altıncı sınıf sosyal bilgiler dersinde öğrencilerin epistemolojik inançlarına, bilişsel farkındalık becerilerine, akademik başarılarına ve bunların kalıcılıklarına etkisi, Yayınlanmamış Doktora Tezi, Adana: Çukurova Üniversitesi Sosyal Bilimler Enstitüsü.

Demir, Ö., Bal, P . 2011.” Bilişsel Koçluk Yaklaşımının tezsiz Yüksek Lisans Matematik Bölümü Öğrencilerinin Görüşleri Açısından İncelenmesi”. Elektronik Sosyal Bilimler Dergisi, 10 (37), 224-243.

Diaz, K.A. 2013. Employing National Board Certification Practices With All Teachers: The Potential of Cognitive Coaching and Mentoring. Doctoral Dissertation. Arizona State University, America.

Dougherty, P. A. 2000. The effects of Cognitive Coaching training as it pertains to: Trust building and the development of a learning community for veteran teachers in a rural elementary school (Doctoral dissertation). Retrieved from ProQuest Dissertations and Theses.

Edwards, J. L., \& Newton, R. R. (1994c, October). Qualitative assessment of the effects of Cognitive Coaching training as evidenced through teacher portfolios and journals. (Research Rep. No. 1994-3). Evergreen, CO: Author.

Edwards, J., Newton, R.R., (1995). The Effects of Cognitive Coaching on Teacher Efficacy and Empowerment. Paper presented at the Annual Meeting of the American Educational Research Association (SanFrancisco, CA, April 18-22, 1995). http://eric.ed.gov/?id=ED388654

Edwards, J. L., \& Green, K. 1997. The effects of Cognitive Coaching on teacher efficacy and empowerment. (Research Rep. No. 1997-1). Evergreen, CO: Author.

Edwards, J. L., Green, K., Lyons, C. A., Rogers, M. S., Swords, M. 1998. The effects of Cognitive Coaching and nonverbal classroom management on teacher efficacy and perceptions of school culture. Paper presented at the annual meeting of the American Educational Research Association, San Diego, CA

Edwards, J. L. (2014). Cognitive Coaching ${ }^{S M}$ : A synthesis of the research $\left(11^{\text {th }}\right.$ ed.). Highlands Ranch, CO: Thinking Collaborative.

Eger, K. A. 2006. Teachers' Perception of the Impact of Cognitive Coaching on Their Teacher Thinking and Behaviors. Doctoral Dissertation. Retrieved from ProQuest Dissertations and Theses Global.

Ellison, J., Hayes, C. 2009. Cognitive Coaching. J. Knight (Ed.), Coaching Approaches and Perspectives. Thousand Oaks, CA: Corwin Press, pp. 70-90.

Evans, R. E., Jr. 2005. Utilizing Cognitive Coaching to enhance the implementation of recommended middle school instructional strategies (Doctoral dissertation). Retrieved from ProQuest Dissertations and Theses.

Evered, R., Selman, J. 1989. "Coaching and the Art of Management”, Organizational Dynamics, $18,116-132$. 
Fine, J. C., Kossack, S. W. 2002. "The Effect of Using Rubric-embedded Cognitive Coaching Strategies to Initiate Learning Conversations", Journal of Reading Education, 27 (2), 31 37.

Flanders, N. A. (1976). Interaction Analysis and Clinical Supervision. Journal of Research and Development in Education, 9, (2), 47-56.

Foster, N. 1989. The impact of Cognitive Coaching on teachers' thought processes as perceived by cognitively coached teachers in the Plymouth-Canton Community School District (Doctoral dissertation). Retrieved from ProQuest Dissertations and Theses.

Freire, P. (1970). Pedagogy of the Oppressed. New York: Seabury Press.

Garmston, R., Hyerle, D. 1988. Professor's peer coaching program: Report on a 1987-88 pilot project to develop and test a staff development model for improving instruction at California State University. Sacramento, CA: Author.

Garmston, R., Linder, C., Whitaker, J. 1993. "Reflections on Cognitive Coaching". Educational Leadership, 51(2), 57-61.

Goldhammer, R., Anderson, R. H, \& Krajesk1, R. J. (1980). Clinical Supervision: Special Methodsfor the Supervision of Teachers. 2nd Ed. New-York, HoltlRinehartlWiston.

Gomez, L. R, (2005). Cognitive coaching: Bringing the ivory tower into the classroom. Unpublished, Ph. Dissertation, The Univerty of Nort Carolina. Educational Leadership College of Education, Charlotte.

Gonzalez, L. J. 2009. Los cinco estados de la mente en el counseling espiritual (Doctoral dissertation. Universidad Iberoamericana, México, D. F.) Retrieved from http://www.uia.mx/.

Gonzales Del Castillo, A. 2015. Cognitive Coaching as a form of Professional Development in a Linguistically Diverse School (Doctoral Dissertation). Retrieved from ProQuest Dissertation and Theses Global.

Gündüz, Y., Balyer, A. (2011). Eğitim Denetiminde Alternatif Yaklaşımlar. M.Ü. Atatürk Ĕ̈gitim Fakültesi Eğitim Bilimleri Dergisi, 33, 61-78.

Henry, A. G. (2012). Cognitive Coaching: An Examination of the Reflective Journaling of Teacher Candidates. Doctoral Dissrtationa, Baylor University, Texas.

Hase, S., Kenyon, C. 2003. "Heutagogy and developing capable people and capable workplaces: strategies for dealing with complexity", Proceedings of The Changing Face of Work and Learning conference, Alberta, Sept 25-27. Available at http://www.wln.ualberta.ca/events_con03_proc.htm

Henry, A. G. 2012. Cognitive Coaching: An examination of the reflective journaling of teacher candidates (Doctoral dissertation). Retrieved from ProQuest Dissertations and Theses.

Irons, N. A. 2014. Coaching for Questioning: A Study on the Impact of Questioning (Unpublished Capstone Action Research project). Fielding Graduate University, Santa Barbara, CA.

Jaede, M., Brosnan, P., Leigh, K., Stroot, s. 2014. "Teaching to Trabsgress: How Cognitive Coaching Influences the Apprenticeship Model in Pre-service Urban Teacher Education", Annual meeting of the American Educational Research association, Philedelphia, PA. 
Kiliç, F. ve Demir, Ö. 2012. Sınıf öğretmenliği öğrencilerinin bilişsel koçluk ve bilişsel esnekliğe dayalı öğretim ortamlarının oluşturulmasına ilişkin görüşleri. İlköğretim Online, 11(3), 578-595.

King, A. 1993. "From Sage on the Stage to Guide on the Side”, College Teaching, 41 (1), 30-35.

Rogers, C. 1951. Client-centered Therapy. Boston: Houghton Mifflin.

Knaebel, D. R. 2008. Exploring the experiences of a literacy coach in a Reading First school in Indiana (Doctoral dissertation). Retrieved from ProQuest Dissertations and Theses.

Krpan, M. M. 1997. Cognitive Coaching and efficacy, growth, and change for second-, third-, and fourth-year elementary school educators (Master's thesis). (Doctoral dissertation). Retrieved from ProQuest Dissertations and Theses Global.

Levy_Feldman, I. 2018. "The good teacher for the twenty-first century: a "mentoring teacher" with heutagogical skills", International Journal of Mentoring and Coaching in Education, 7 (2), 177-190.

Lin, V. 2012. Preparing Future Early Childhood Teachers? A mMixed Methods Investigation of Inquiry-base Field Experiences.(Doctoral Dissertation). Retrieved from ProQuest Dissertationa and Theses Global.

Loeschen, S. 2012. Generating reflection and improving teacher pedagogy through the use of Cognitive Coaching in a mentor/beginning teacher relationship (Doctoral Dissertation). Retrieved from ProQuest Dissertations and Theses.

Maginnis, J. L. 2009. The relationship clinical faculty training has to student teacher self-efficacy (Doctoral dissertation). Retrieved from ProQuest Dissertations and Theses Global

Mclymont, E. F. 2000. Mediated learning through the coaching approach facilitated by Cognitive Coaching (Doctoral dissertation). Retrieved from ProQuest Dissertations and Theses

Mclymont, E. F., Costa, J. L. 1998. Cognitive Coaching: The vehicle for professional development and teacher collaboration. Paper presented at the annual meeting of the American Educational Research Association, San Diego, CA.

Novak, J. D., Gowin, D. B. 2004. Learning How to Learn $\left(19^{\text {th }}\right.$ ed). United Kingdom: The Press Syndicate of the Cambridge University Press.

Powell, W., \& Kusuma_Powell O. 2007. "Coaching Students to New Heights in Writing". Educational Leadership: Engaging the Whole Child (online only), 64(Summer).

Reed. R. A. (2006). Case Study of the Implementation of Cognitive Coaching by an Instructional Coach in a Title I Elementary School. Doctoral Dissertation, Texas A. M. University.

Reiss, K. (2006). Leadership Coaching for Educators: Bringing Out the Best in School Administrators. Thousand Oaks: Corwin Press.

Rennick, L. W. (2002). The relationship between staff development in balanced literacy instruction for kindergarten teachers and student literacy achievement. Dissertation Abstracts International, 63 (5), 1796. (University Microfilms No. 3051831).

Rinald, L. 2013. The effects of learning about the Five States of Mind on elementary children in grades 3, 4, and 5. Fielding Graduate University Doctoral dissertation. Retrieved from ProQuest Dissertations and Theses. 
Robinson, J. M. 2011. Supporting National Board Candidates Via Cognitive Coaching Conversations and Communities of Practice. (Doctoral Dissertatio). Retrieved from proQuest Dissertations and Theses Global.

Rogers, C. 1983. Freedom to learn for the Eighties. Columbus, OH: Charles E. Merrill.

Rogers, W. T. Hauserman, C. P., Skytt, J. 2016. "Using Cognitive Coaching to build school leadership capacity: A case study in Alberta". Canadian Journal of Education, 39(3), 1-29.

Rowley, J. B. (1999). Supporting teacher: The Good Mentor. Educational Leadership. 56(8), 2022.

Rutgers. L. (2012). Coaching Foundation Phase Literacy Teachers As Leaders in a School in the Western Cape Province: A Professional Development Strategy. Doctoral Dissertation. Stellenbosch University, South Africa.

Scholosser, J. L. (1998). The impact of Cognitive Coaching on the thinking processes of elementary school teachers (Doctoral dissertation) Retrieved from ProQuest Dissertations and Theses. (UMI No. 9821080)

Shaw, R. D. 2014. “How Critical Is Critical Thinking?”, Music Educators Journal, 101(2), 65-70.

Skytt, J. K., Hausermann, C. P., Rogers, W. T., Johnson, J. B. 2014. Cognitive Coaching: Building school leadership capacity in Alberta's education system Leader2 Leader Project (L2L). Program report. Edmonton, AB, Canada: The Alberta Teachers' Association.

Slinger, J. L. (2004). Cognitive Coaching: Impact on student and influence on teachers. Dissertation Abstract International, 65(7),2567. (University Microfilms No. 3138974).

Smith, M. C. 1997. Self-reflection as a means of increasing teacher efficacy through Cognitive Coaching (Master's thesis). Retrieved from ProQuest Dissertations and Theses Global.

Spence, G.B. \& Oades, L.G. (2011). Coaching with self-determination in mind: Using theory to advance evidence-based coaching practice. International Journal ofEvidence-based Coaching and Mentoring, 9(2),37.

Stephenson, J., Laycock, M. 2005. Using Learning Contrats in Higher Education. (Digital Ed.). New York: Routledge.

Swanson, L. J., (1995). Learning styles: A review of the literatüre, ERIC Document No. ED 387067.

Townsend, S. (1995). Understanding the effects of cognitive coaching on student teachers and cooperating teachers. Doctoral Dissertation. Retrieved from ProQuest Dissertations and Theses. (304185850).)

Tümen Akyıldız, S. 2015. Bilişsel Koçluk Destekli Yansıtıcı Öğretim Yaklaşımının İngilizce Öğretiminde Öğrencilerin Akademik Başarısına, kalıcılığa, Yansıtıcı Düşünme ve Üstbiliş Becerilerine Etkisi. Yayınlanmamış Doktora Tezi, Elazı̆̆, Fırat Üniversitesi, Eğitim Bilimleri Enstitüsü.

Tümen Akyıldız, S. Semerci, Ç (2016). The cognitive coaching-supported reflective teaching approach in English language teaching: Academic and permanence success. Educational Research and Reviews. 11, 20, 1956-1963.

Ushijıma, T. M. 1996. Five State of Mind Scale for Cognitive Coaching: A measurement Study (Doctoral Dissertation). Retrieved from ProQuest Dissertations and Theses. 
Wheatley, M. J. (2005). Finding our way: Leadership for an uncertain time. San Francisco: BerretKoehler.

Whitmore, J. (1995). Coaching for Performance. London: Nicholas Brealey Publishing.

Witherspoon, R. \& White, R. P. (1996). Executive Coaching: A continuum of roles. Consulting Psychology Journal: Practice \& Research, 48(2),124-133.

Wooten Burnett, S. W. 2015. Cognitive Coaching ${ }^{\text {SM}}$ : The impact on teacher candidates' teacher efficacy (Doctoral dissertation). ProQuest Dissertations and Theses Global.

Yust, J. (1998). Cognitive Coaching: A Multiple Case Study. A Dissertation for the Degree of Master of Education. Brock University, St. Catharines, Ontario. 